\title{
TRIÁLOGO: APROXIMACIONES TEÓRICAS A LA SOCIOLOGÍA DEL CONSUMO
}

\section{TRIALOGUE: THEORETICAL APPROACHES TO THE SOCIOLOGY OF CONSUMPTION}

Carlos Soldevilla Pérez: Instituto de Sociología Aplicada de Madrid. carlos.soldevilla@arrakis.es

\section{CURRÍCULUM VITAE DE CADA AUTOR}

Doctor en Sociología por la Universidad Complutense. Profesor en dicha universidad de Teoría Social Clásica e Ilustración y Romanticismo en la génesis de la Teoría Sociológica Española. Es autor de varios artículos científicos y libros derivados de su labor universitaria.

\section{RESUMEN}

Este artículo realiza tres aproximaciones teóricas a la Sociología del consumo, desde la perspectiva apocalíptica (el consumo como construcción social por parte de la oferta), en la que se incluyen autores como Karl Marx, Thorstein Veblen o Jean Baudrillard; desde la perspectiva anfibológica (el consumo visto como "el encanto de un mundo desencantado") apoyada por autores como George Simmel, Max Weber o Walter Benjamin; y desde la perspectiva apologética (el consumo desde la perspectiva de los que prefieren "desayunar en Tiffany's") defendida por autores como Herbert Spencer, Mary Douglas o George Bataille, entre otros. De ahí que el 
título de este trabajo comience con la palabra "triálogo", que no quiere decir tres logos, sino conversación a través del logos entre las tres grandes maneras de cifrar la sociología del consumo. Cada una de ellas tiene sus pros y sus contras, por eso interpelándolas y contrastándolas, esto es, haciéndolas conversar, es más probable que se encuentren líneas complementarias que compensen sus déficits particulares, a la par que incentiven sus mejores logros. Pues, si la sociología del consumo pretende ser un campo autónomo de conocimiento y praxis, algo más que un mero comentario alternativo a las limitaciones y fallos de las teorías económicas al uso, necesita de una robusta teorización que incorpore un verdadero triálogo entre las tres grandes perspectivas.

\section{PALABRAS CLAVE}

Sociología del Consumo - Teoría económica - Triálogo - Oferta - Mundo

\section{ABSTRACT}

This article makes three theoretical approaches to the sociology of consumption, from the apocalyptic perspective (consumption as a social construction by the offer), which included authors such as Karl Marx, Thorstein Veblen and Jean Baudrillard, from the perspective amphibological (consumption seen as "the charm of a disenchanted world"), supported by authors such as George Simmel, Max Weber, Walter Benjamin, and apologetic perspective (consumption from the perspective of those who prefer "Breakfast at Tiffany's") defended by authors such as Herbert Spencer, Mary Douglas or George Bataille, among others. Hence the title of this work begins with the word "trialogue", which means three logos, but logos conversation via the three great ways to encrypt the sociology of consumption. Each has its pros and cons, so questioned and contrasting, that is, making conversation, the more likely they are complementary lines to compensate for specific deficits, at 
the same time encourage their best achievement. For if the sociology of consumption intended to be an autonomous field of knowledge and practice, more than a mere comment alternative to the limitations and failures of economic theory to use, requires a robust theorizing that incorporates a real trialogue between the three major perspectives.

\section{KEY WORDS}

Sociology of Consumption - Economic Theory - Trialogue - Offer - World

\section{ÍNDICE}

\section{Introducción}

2. Perspectiva apocalíptica: el consumo como construcción social por parte de la oferta.

2.1 Karl Marx y la teoría crítica, o el consumo como alienación.

2.2 Thorstein Veblen y John K. Galbraith, o el consume como diana de la envidia generalizada.

2.3 Jean Baudrillard, o el consumo como lenguaje de los objetos-signos.

2.4 Fredric Jameson, o el consumo como ideología del capitalismo tardío.

2.5 Zygmun Bauman, o el giro desde la "ética del trabajo" a la "estética del consumo".

2.6 Michel de Certeau, o el consumo como subversión.

3. Perspectiva anfibológica: el consumo visto como "el encanto de un mundo desencantado".

3.1 George Simmel, o el consumo como pertenencia y distinción.

3.2 Max Weber, o el consumo como estilo de vida de la personalidad valiosa.

3.3 Walter Benjamin, o el consumo postmoderno del flâneur.

3.4 Pierre Bourdieu, estratificación y distinción social a través del consumo. 
3.5 George Ritzer, o el consumo como el "encanto de un mundo desencantado".

4. Perspectiva apologética: el consumo desde la perspectiva de los que prefieren "desayunar en Tiffany's".

4.1 Herbert Spencer, o la evolución hacia un consumo más diverso y plural.

4.2 Mary Douglas y Baron Isherwood, en defensa del consumidor.

4.3 George Bataille y el consumo improductivo.

4.4 Michel Maffesoli, o el consumo tribal, orgiástico y errático.

4.5 Claude Grignon y Jean Claude-Passeron, o las condiciones de posibilidad simbólicas del consumo popular.

4.6 Mike Featherstone, Pasi Falk y Colin Campbell: las nuevas teorizaciones sobre la cultura del consumo.

5. Triálogo, a modo de conclusión.

6. Bibliografía.

TEXTO:

\section{Introducción}

La actual sociedad derivada de la tercera revolución industrial, la revolución tecnológica, avanza hacia unas nuevas interrelaciones entre el trabajo, el consumo y el ocio, que suponen un cambio decisivo en la historia de la modernidad; por eso quizá sea oportuno comenzar este trabajo sobre las distintas concepciones sociológicas del consumo, introduciendo de forma sucinta los diferentes contextos históricos que han dado lugar a su aparición, sin cuya remisión es imposible tener una visión de conjunto de dichas sustantivas relaciones y de su evolución a través del decurso histórico. El diagnostico weberiano (1901) nos proporciona un punto de 
partida pertinente, según el cual el mundo moderno se fue organizando en torno a una "ética protestante" en la que la valoración del trabajo alcanzaba el rango de salvación religiosa.

De este modo, siguiendo a Weber, el protestantismo ascético aparece como condición básica para el despegue del modo de producción capitalista y como el motor de su desarrollo. El asceta protestante se convierte, por tanto, en el individuo trabajador, esforzado, eficaz, ahorrador e inversor que no utiliza sus obras laborales como bonos de salvación, sino como modos de ahuyentar el miedo a la condenación, asegurándose en la convicción de que el triunfo económico en esta vida es una señal inequívoca de su pertenencia al grupo de los elegidos. La austeridad y el ahorro eran atributos fundamentales de este monje secular, que practica la santidad laica del trabajo virtuoso, alejándose del consumo que, en las sociedades del primer capitalismo de producción, adquiere un cariz de madre de todos los vicios.

Pero con el comienzo de la segunda revolución industrial, durante los primeros años del siglo XX, las cosas van a cambiar de forma notoria. Por un lado crece progresivamente la productividad, antes y después de la IGM. Posteriormente, la introducción de la racionalización en el sistema de organización social del trabajo diseñado por Henry Ford, el fordismo, pautó los procesos de racionalización empresarial, que permitieron una producción en cadena que atendiese a la exigencia de crecimiento económico en economías de escala, mientras se satisfacían las necesidades de armamento y de acumulación de bienes de capital, junto con la producción de bienes de consumo para la subsistencia de la clase trabajadora y de bienes ociosos para el consumo de las clases adineradas.

Sin embargo, pronto el fordismo tuvo una primera consecuencia indeseada, la crisis de sobreproducción de comienzos de los años 1930s. Crisis de la que los decisores y estrategas del sistema industrial extrajeron la conclusión fundamental de que la 
única forma de equilibrar el desarrollo de la rentabilidad capitalista era transformando la estructura social, rígidamente dualista y jerárquica, orientándola hacia una dirección que incorporase a la fuerza de trabajo como una de las principales fuentes de consumo. Por ello, una de las maneras de remontar la crisis consistió en combinar el fordismo con la teoría de J. M. Keynes (1936), para conformar un proceso de desarrollo regulado por una serie de medidas que mejoraron las condiciones sociolaborales (aumentos salariales y mejora en la distribución de la renta), destinadas a incentivar las prácticas de consumo de los trabajadores, creando así las condiciones de posibilidad del "consumo de masas", capaz de absorber los potenciales e indeseados niveles de sobreproducción. Así, tras la IIGM, el desarrollo tecnológico y productivo continuó imparable, y ligado a la creación de una poderosa industria del marketing y la publicidad, condujo al pleno empleo y a la extensión del consumo en las sociedades industrializadas occidentales.

En consecuencia, este primer consumo de masas, no cabe entenderlo sin el pacto keynesiano entre capital (asegurándose sus tasas de acumulación y rentabilidad) y trabajo (mejoras socioeconómicas y acceso a la participación en la gestión empresarial), que cristaliza en el "Estado de Bienestar", y cuyo impacto social no se hizo esperar. De esta forma, a lo largo de la década de 1950s, se va mejorando progresivamente el nivel de vida de la población laboral, dado el aumento de las inversiones destinadas a salud, enseñanza, seguridad social y mayor tiempo de ocio disponible. Estas mejoras en las condiciones de vida de los trabajadores se tradujeron en un despliegue sin precedentes del sistema productivo de postguerra que, a su vez, implementó una nueva moral hedonista proclive al consumo, que reemplazó la vieja ascesis del trabajo y el ahorro, para así estimular la demanda masiva de bienes y servicios. Por otro lado, el desarrollo del marketing y la publicidad permitió aguzar aún más la demanda, apareciendo esa figura del consumidor insatisfecho, ávido de novedades y de productos que le singularicen frente a los demás. Así, el nuevo evangelio del consumo, difundido a través de los expertos en los nuevos medios de 
comunicación de masas, confiere a la oferta de productos no sólo la satisfacción de las necesidades primarias, sino que pasa a asociar ciertos objetos de consumo con símbolos de estatus, prestigio y poder social. De esta forma consumir se vuelve el nuevo carpe diem que, como ethos regio, vectorializa gran parte de los procesos y prácticas sociales.

Por todo ello, la esfera del consumo se ha convertido en una dimensión sociocultural importantísima, pasando a ocupar un lugar central en el desarrollo de las teorías científico-sociales por pleno derecho. De ahí, que para la teoría económica mainstream sea la demanda el foco de su atención, siendo el objeto de estudio habitual los factores que definen y/o modifican la conducta de un consumidor entendido como "preferidor racional", tendiendo a excluir el análisis de las necesidades humanas como una base fundamental para el establecimiento de políticas sociales más ponderadas y justas. Mientras que, por otro lado $\mathrm{y}$, desde el punto de vista sociológico, el consumo es entendido de diversas maneras que, en líneas generales, cabría sintetizar en tres posturas que van desde la óptica que considera que es la oferta la que la que genera su propia demanda, hasta las visiones que entienden el consumo configurado por el libre arbitrio de la demanda, pasando por el punto intermedio del consumo entendido como forma de interacción social sustantiva (cultural, simbólica, socio-psicológica, etc.).

Posturas que nos permiten presentar ahora una aproximación topológica a los diversos posicionamientos de la teoría sociológica en torno a la polémica cuestión del consumo. Primero, la de los "apocalípticos", que, en la nostalgia de la comunidad perdida, siguen prefiriendo "personas que los acompañen" a "objetos que les confirmen". Una segunda postura es la de los "anfibológicos", que analizan pros y contras de este fenómeno, pero sin incidir en ninguno de los extremos, y cuya perspectiva sobre el consumo podría metaforizarse a través del lema propuesto en su última obra por George Ritzer (1999), esto es, el del: "encanto de un mundo 
desencantado". Por último, tendríamos a los "apologistas" que, de una forma coloquial, cabe definir como "los que prefieren desayunar en Tiffanys", tendentes a visualizar el consumo como una amplificación de la libertad y la expresividad de la personalidad individual y colectiva. A continuación paso a glosar el desarrollo de las teorías sociológicas sobre el consumo en torno a este eje triádico.

No obstante, antes de pasar al siguiente epígrafe, creo pertinente señalar que este trabajo defiende que la sociología debe dar razón y cuenta de las diferentes tendencias emergentes de una manera rigurosa, lo cual no debe suponer la identificación con alguna de ellas. Lo que sigue tiene mucho de relato esquemático, escrito a un alto nivel de generalidad, que reconoce que estas formulaciones necesitan ser contrastadas en principio por el debate y, finalmente, por el análisis empírico, que proporcione el suficiente contraste con la específica realidad social a la que se refiera.

\section{Perspectiva apocalíptica: el consumo como construcción social por parte de la oferta}

Los teóricos de la perspectiva apocalíptica tienden a caracterizar el consumo como el más robusto recurso para la manipulación social. Destructor, además, de los valores y normas propios del trabajo y el pleno empleo, así como de los valores y formas de vida tradicionales (entiéndase las concernientes a las del sector primario de la economía) e "industriales" (sector secundario). Sitúan su foco de estudio en la oferta, a la que acusan de "construir" interesadamente las pautas de consumo de la demanda. Por todo ello cabría definir su tratamiento del consumo como socioconstruccionista.

Suelen utilizar una metodología dialéctica e histórica para conceptualizar las cuestiones relativas a la producción y consumo, que pasan a ser consideradas como 
dos posiciones opuestas, de las cuales la constelación de factores que componen la oferta productiva (el capital, sus estrategas y decisores, junto con los expertos en marketing y publicidad) es incuestionablemente la dominante, mientras que la pasividad y subordinación vicaria caracterizan el perfil de la demanda. Su crítica se desdobla en dos contenidos que, aunque suelen aparecer combinados, aquí separamos a efectos de clarificar su exposición. Por un lado se critica a la sociedad de consumo por su capacidad de manipulación ideológica y seductora del consumidor y, por tanto, se la considera un culmen de la lógica del sistema de producción capitalista (Marx, Veblen, Escuela de Frankfurt). Mientras que, por otro lado, se considera que esta lógica de dominación además origina un grave proceso de "distorsión/ desorden cultural", esto es, de anomia y desestructuración de los valores y normas que lo inauguraron (Baudrillard, Jameson, Certeau, Bauman).

\subsection{Karl Marx y la teoría crítica, o el consumo como alienación.}

Para la economía clásica son las leyes del mercado, con su efecto corrector de la "mano invisible" (según Adam Smith), las que posibilitan al fin y al cabo que terminen acoplándose articuladamente los diferentes intereses de la oferta y de la demanda. Por ello, desde la perspectiva del utilitarismo, que impregna toda la economía clásica hasta nuestros días, el objeto de toda producción es el consumo, con individuos que tienden a maximizar sus satisfacciones a través de la compra de un rango de bienes siempre en expansión. Pero el problema central de la teoría clásica liberal consiste en dar por resuelto el problema del ajuste entre la producción (sin definición alguna de las necesidades: prioritarias, relativas, ociosas, suntuarias, etc.) y el consumo (sin tener en cuenta las formas de vida, ni las desiguales capacidades adquisitivas de los consumidores) a través de la competencia que establece el mercado, partiendo del supuesto de lo que se ha denominado "soberanía del consumidor", concepto que expresa que el consumidor es el auténtico protagonista y garante del doble proceso de producción-consumo. 
No es de extrañar que la crítica marxiana a la economía liberal se centrase en trasladar el eje de atención hacia la oferta (constructora de las necesidades y deseos del consumidor), denunciando, simultáneamente, el supuesto ideológico de la autonomía de las necesidades individuales en su estatuto regio como consumidor. Por ello, Karl Marx, en su "Contribución a la crítica de la economía política", nos desentraña el problema del corpus de la economía liberal, desvelando su ideológica/interesada construcción de las esferas de la producción y del consumo: "La producción le da al consumo su determinación, su carácter, su finish. De la misma forma que el consumo le daba al producto su finish como producto, la producción le da su finish al consumo. En suma: El objeto no es un objeto en general, sino un objeto determinado que tiene que ser consumido de una forma determinada, que ha de ser a su vez mediada por la producción misma. El hambre es hambre, pero el hambre que es saciada con carne guisada comida con cuchillo y tenedor es un hambre muy diferente de aquella que es saciada devorando carne cruda con la ayuda de las manos, uñas y dientes. No sólo el objeto del consumo, sino también la forma del consumo es producida, en consecuencia por la producción, no sólo objetiva sino también subjetivamente. La producción crea, por lo tanto, a los consumidores" (K. Marx. 1857-1858 : 15).

Sin embargo, esta magnífica plomada de la "producción social de los consumidores" quedó como proyecto incompleto, al centrar Marx su atención sobre las relaciones sociales de producción y el significado total del dinero como instrumento (valor de uso), precio (valor de cambio) y símbolo ("fetichismo de la mercancía") en el modo de producción capitalista, dejando de lado los aspectos relativos a la reproducción social, que permanecen incoados en "El capital" (1867b : 71 y ss.), cuando Marx hipotetiza que lo característico de la relación de poder propia del segundo momento capitalista (de producción-reproducción) es el paso de la "subsunción formal a la subsunción real de trabajo en capital", o lo que es lo mismo, el paso de la 
construcción "ideológica" a la construcción "material" de la subjetividad y de sus correspondientes "formas de vida", de todos los agentes participantes en la producción (empresarios, trabajadores y consumidores).

Por otro lado, los objetos de consumo, dentro de la óptica marxiana, se limitan a cubrir las necesidades prioritarias de las personas. Naturalmente, Marx pensaba en las acuciantes necesidades de la clase trabajadora, prestando preeminentemente su atención a la intervención del dinero como valor de cambio en su precio y a la consiguiente fetichización de las relaciones sociales, las establecidas entre productores de capital y de trabajo; y desinteresándose respecto a las prácticas y relaciones que concurren en el consumo. Así, mientras la aproximación de Marx puede mostrarnos cómo el valor de cambio, en el capitalismo, construye las relaciones sociales en el proceso de producción, su teorización no aborda la comprensión de los objetos desde el punto de vista del consumo y de los consumidores.

Este handicap, en mi opinión, se traslada a la posterior sociología crítica, que presupone que los actores sociales viven casi íntegramente alienados bajo el imperio de la "falsa conciencia", y que la verdad de la experiencia y del deseo sólo afloran cuando la luz de la crítica desmantela el modelamiento de la acción social por parte de una oferta apoyada por las baterías del marketing y la publicidad. De ahí que no logre explicar ni comprender el fenómeno del consumo de masas, porque no lo admite en sus esquemas, salvo para criticarlo como vía de la actual manipulación social, denunciando como falaces o inútiles el reconocimiento de las cuestiones relativas a la agencia personal y colectiva en la sociedad de consumo.

La tendencia profunda de esta teoría sociológica consiste en imaginar la sociedad como un todo manipulado por la "administración total" que impone la misma lógica de racionalidad instrumental en la esfera de la producción y en la esfera del consumo 
(Horkheimer y Adorno. 1944); o bien la "cosificación" inducida desde la producción (Lukács. 1922); o la acción de los "aparatos ideológicos de dominación" socializadora (Althusser y Balibar. 1967), que genera una "unidimensional y totalitaria alienación" (Marcuse. 1954). Y es que, cuando se aspira al poder (anhelo que atraviesa a todos los autores apocalípticos) se necesita producir, acumular y retener hasta el momento oportuno del kairós revolucionario. ¿Qué interés puede tener entonces el comportamiento contrario inherente a las convencionales prácticas de consumo?. Quizá por ello, la tarea de la sociológica crítica se mueve como aparato de descrédito sistemático de la socialización consumista, que sólo la entiende como coacción, acentuación de la alienación y alimentación del sistema de los objetos.

Por lo tanto, los "teóricos críticos" se inclinan a ver en el consumo un socavamiento de los valores de uso que potencian el intercambio entre personas al margen de la hegemonía del valor de cambio, la pérdida de valores solidarios y el desdibujamiento de la estructura de clases, agenciado por el complot de las clases dominantes con los decisores de las grandes empresas de mercancías y las agencias de publicidad. El ocio y el tiempo libre, las artes y la cultura en general llegan a ser modeladas por el sistema de razón instrumental, que rige tanto la producción como el consumo, el cual, a través de la industria de la cultura, construye interesadamente para su rentabilidad una percepción social del consumo y del ocio, mientras mina los propósitos que aún se mantienen autónomos al valor de cambio: los valores tradicionales de las culturas vernáculas; o bien los de la "alta cultura", en su apuesta por los sublimes ideales: ora del "alma bella" romántica, bien de la "autonomía" kantiana, o de la "autorrealización" hegeliana.

En suma, desde esta perspectiva se defiende que el sistema de producción capitalista ha promovido el triunfo del valor de cambio, y que el cálculo racional domina todos los aspectos de la vida, y para el cual todas las diferencias esenciales, tradiciones culturales y calidades (en las formas de vida) llegan a ser transformadas en 
cantidades, que traducidas a valor de cambio y homogeneizadas a través del mercado se convierten en simples mercancías. Por ello, esta utilización de la lógica del capital puede dar cuenta de la calculabilidad progresiva y la destrucción de los residuos de la cultura tradicional y de la alta cultura.

Por ello, la sociología crítica da finalmente a entender que existe una especie de perversión en la sociedad de consumo misma, como si los seres humanos estuvieran transformados en autómatas, tan profundamente alienados que ni siquiera podrían adquirir conciencia de sus relaciones con el medio social. Atrincherada detrás de su empalizada crítica, protegida por su impermeable rigorismo de las tentaciones y veleidades de la sociedad de consumo, decide prescindir del "fetichismo de los objetos" y no "desayunar en Tiffanys", en espera del momento de ruptura que dé paso a la vida comunista o comunitaria de la "buena compañía". La aproximación de la teoría critica al consumo, por tanto, tiene dificultad para dirigirse hacia las prácticas y las experiencias de consumo actuales, por considerar las industrias de la cultura como factorías productoras de una cultura de masas homogénea, alienada y sumisa a los dictados de la oferta.

\subsection{Thorstein Veblen y John K. Galbraith, o el consumo como diana de la envidia generalizada.}

El primer trabajo sobre la distinción social a través de consumo se debe a Thorstein Veblen, para el cual las bases de la buena reputación del ciudadano en sociedad yacen tanto en su capacidad pecuniaria, como en su disposición al consumo ostentoso. En otras palabras, las dos formas privilegiadas de indicar el estatus pecuniario de uno, de acuerdo con Veblen, son el ocio y el consumo conspicuo. Por ello, Veblen es el primer autor que defiende expresamente que los fenómenos del consumo dependen de la estructura social, y no de las necesidades naturales y de su libre satisfacción por parte del consumidor a través del mercado. 
Así en su "Teoría de la clase ociosa" (1899) considera que el "consumo ostentoso" es una señal de prestigio de la clase ociosa, junto con las anacrónicas prácticas, derivadas de la "era arcaica", de las "hazañas" deportivas (1899 : 20-21), los "regalos" y las "fiestas (1899 : 82). Para Veblen, esta norma de "consumo ostentoso" detentado por la clase ociosa era una poderosa fuerza de dominio que, a la par, establecía referencias de identidad y de estilo de vida a seguir miméticamente por las clases laboriosas. Pues, según Veblen, tras el instinto de conservación, la propensión a la emulación y la pasión de la envidia son los motivos sociopsicológicos más fuertes y, además, los que explican la constitución de los lazos sociales, pues el miedo a la falta de reconocimiento social lleva a los individuos de las clases laboriosas (las únicas que producen los bienes) a consumir como lo hace la clase ociosa, que, sin trabajar, asienta sin embargo con sus pautas de ocio y consumo las referencias de identidad y estilo de los demás grupos sociales.

Resulta entonces que, según Veblen, el sistema social es un sistema asimétrico y corrupto, pues se asienta no sólo en una desigual relación entre clases laboriosas y clases ociosas, sino que, además, se ancla sobre el principio motivacional de la "envidia generalizada", que se dinamiza a través del establecimiento de referencias suntuarias, cuya diana material son los objetos de consumo ocioso y ostentoso, a la par que asienta la rivalidad entre los individuos y grupos por acceder a ellas; y, por último, suscita la "imitación vicaria" (Veblen. 1899 : 66-67) a que se ven abocados aquéllos que, no pudiendo acceder a los bienes ociosos y suntuarios, se ven obligados a la imitación tanto del ocio como del consumo ostentoso de los superiores en rango. Luego, la conclusión más importante, para Veblen, es que el sistema socioeconómico para subsistir necesita crear y sostener una envidia generalizada respecto a las necesidades superfluas (ociosas, ostentosas), que son las que contienen un alto grado de significación en las ratios del prestigio, el poder y la riqueza, y cuyo consumo 
instituye una interesada y asimétrica estratificación social afín a los intereses de las clases dominantes y ociosas.

Esta acerada y anticipada crítica social, a mi juicio, no podría entenderse sin el mecanismo de compensación sociopsicológico que concurre en nuestro autor. Pues, cabe hipotetizar que, Veblen, ciertamente vividor y mujeriego (Diggins. 1978 : 240), no hubiese desarrollado su teoría sin el acontecimiento marcador de la expropiación de tierras comunales de su familia natal noruega. Expropiación que, dada la pertenencia a un sistema de creencias puritano protestante, fue vivida como una triple catástrofe: como una desposesión material de tierras, como un impedimento al desarrollo del trabajo como agricultores y ganaderos; $\mathrm{y}$, sobre todo, como un signo de condenación secular, para unas gentes, cuyo credo (como más adelante veremos con Weber), les sancionaba negativamente, pues el acceso a la gracia se verificaba mediante el éxito inmanente de los frutos del trabajo/profesión (beruf).

Por tanto, en el trabajo de Veblen, el ocio y el consumo conspicuo aparecen como formas de preservar el rango y estatus de uno; y afecta, en su medida, a todos los grupos sociales: "Las personas sufren un grado considerable de privaciones de las comodidades o de las cosas necesarias para la vida, con objeto de poderse permitir lo que se considera como una cantidad decorosa de consumo derrochador" (1899: 174). Lo que observamos de singular en la formulación de Veblen es que es el primer autor que divide las necesidades en básicas y de prestigio social y que, incluso, jerarquiza estas últimas sobre las primeras, con lo cual inaugura una nueva definición y estratificación de las necesidades de consumo, privilegiando el consumo que, ulteriormente, pasará a denominarse "sígnico" (Baudrillard), "simbólico" (Jameson) o "estético" (Bauman).

Por otro lado, este análisis de la conducta emulativa/envidiosa, que aparece como el pilar central de la crítica de Veblen a la incipiente sociedad de consumo 
norteamericana de comienzos del siglo XX, da lugar al énfasis de la manipulación por parte de la demanda en la aproximación de John K. Galbraith (1958). De acuerdo con Galbraith, no es posible la libre elección del consumidor, porque más allá de la producción de las necesidades "absolutas" es la oferta, apoyada por las fuerzas de la "publicidad y la emulación", la que "crea" la demanda de necesidades "relativas" (Galbraith. 1958 : 168) de este modo y contra la idea de que el consumidor elige libremente sin influencia externa, afirma Galbraith: "Se podría defender con cierta razón la doctrina de que el consumidor, en tanto que elector, puede escoger libremente entre los bienes privados y los públicos. Pero teniendo en cuenta el efecto dependencia (dado que las necesidades del consumidor son creadas por el mismo proceso que las satisface), el consumidor no puede elegir de este modo. Se encuentra sujeto a las fuerzas de la publicidad y de la emulación, a través de las cuales la producción crea su propia demanda" (Galbraith. 1958 : 247).

De ahí que el aparente "equilibrio social" entre el sector privado (oferta) y el público (demanda) sea falso, y que se traduzca en la ominosa asimetría entre la opulencia privada y la miseria pública, característica que, según Galbraith, define a la sociedad industrial moderna. Asimetría que es reforzada de singular manera por la publicidad, destinada a incentivar el consumo de bienes ociosos y a estimular los efectos emulativo y/o envidiosos en la sociedad por cuenta de la producción privada, mientras que ningún proceso similar actúa en nombre de los servicios públicos: "La publicidad opera exclusivamente, y la emulación, en gran parte, por cuenta de los bienes y servicios producidos por el sector privado. Puesto que la dirección de las empresas y los efectos emuladores actúan sólo por cuenta de la producción privada, los servicios públicos tendrán una tendencia a permanecer retrasados... Las máquinas de la propaganda en masa, en su máximo grado de desarrollo, se apoderan de los ojos y oídos de la comunidad pidiendo más cerveza pero no más escuelas" (Galbraith. 1958 : 247-8). 
Esta desviación de la demanda lejos del consumo de educación tiene serias consecuencias para Galbraith, pues él asigna a la educación un rol crucial para conseguir cierto equilibrio social entre los sectores público y privado, capacitando un consumo más reflexivo e independiente de la manipulación de la publicidad y sus efectos emulativos: "la educación permite a la gente darse cuenta de cómo son manipulados en beneficio del mecanismo que se supone estaba a su servicio" (Galbraith. 1958 : 265). Sin desestimar las diferencias entre las aproximaciones de Veblen y la de Galbraith, su común denominador consiste en que relacionan el consumo con la estratificación social, entendiéndolo, además, como ideología desarrollada por las clases propietarias y ociosas (Veblen) o por la oferta privada (Galbraith), cuyo cometido es asentar las referencias de identidad personal y colectiva, a través de la envidia y la emulación vicaria, incentivadas por el dispositivo publicitario. Cuestiones de fundamental importancia para el posterior desarrollo de la sociología crítica del consumo.

\subsection{Jean Baudrillard, o el consumo como lenguaje de los objetos- signos.}

Heredero de la lógica implacable de la teoría de la "cosificación" y de la "administración total" de Horkheimer, Adorno y Lukács, Baudrillard va a situar el acento de su teoría en la deconstrucción de la cultura tardocapitalista, que él ve epitomizada en la "sociedad de consumo" (1970) y en su estereotipo del "preferidor racional" y su tópica conducta utilitaria, determinada simultáneamente por los intereses de la oferta productiva y por la tendencia hedónica hacia la satisfacción de sus deseos inducida por aquélla. En su ambiciosa teoría, el consumo se convierte en el nuevo "universal" legitimador de la actual lógica de dominación de clase. Por ello $\mathrm{y}$, en contra del leitmotiv de los ideólogos del consumo, prestos a justificar éste por su función social de corrección de las desigualdades sociales (el consumo de una coca-cola es igualitario, esto es, se opone a las jerarquías de clase y de origen), 
Baudrillard afirma: "La lógica cultural de clase en la sociedad burguesa se ha fundado siempre sobre la coartada democrática de los universales. La religión fue un universal. Los ideales humanistas de libertad y de igualdad fueron universales. Hoy, el universal adopta la evidencia absoluta de lo concreto. Son las necesidades humanas y los bienes materiales y culturales los que a él responden. Es el universal del consumo" (Baudrillard. $1972:$ 45).

En la "Crítica de la economía política del signo", Baudrillard extiende el alcance teórico original de Marx introduciendo un nuevo concepto del valor-de-la-forma, nominalmente el del "valor-de-signo", mientras simultáneamente ataca a Marx, y a la doxa marxista, por naturalizar, esto es, por "fetichizar" el concepto del valor de uso en aras a la ingenua "ilusión revolucionara" de la convivencia solidaria en torno a una producción regida por los valores de uso (Baudrillard. 1972 : 259). Según, el sociólogo de Reims, el sistema social capitalista ha ido girando su centro de gravedad durante el XX, desde el campo de la producción al del consumo. Cambio que ha supuesto dos claras etapas. Primero y, coincidiendo con la fase del "capitalismo de producción", la etapa de la eliminación del originario valor de uso de los bienes por la dominación del valor de cambio. Segundo y coincidiendo con el "capitalismo tardío o de consumo", por la hegemonía del valor sígnico sobre el valor de cambio, dada la conexión del objeto de consumo con los "signos" de estatus, tanto por su diseño y ubicación en los determinados segmentos de mercado, como por el plus valor añadido por el marketing y la publicidad.

El consumo, por tanto, constituye, para Baudrillard, el siguiente paso lógico en el cambio social que conviene al desarrollo del capitalismo, tras la gran migración del campo a la ciudad acaecida en el siglo XIX y comienzos del siglo XX. Entonces, las poblaciones rurales tuvieron que abandonar sus tierras y vínculos comunitarios primordiales, para emigrar a las grandes ciudades y ser empleadas en la producción industrial. Ahora, cuando remite el sector secundario, el consumo es el nuevo núcleo 
en torno al cual se ancla la estructura social: "No acabamos de darnos cuenta de cómo la actual domesticación al consumo sistemático y organizado es el equivalente y la prolongación en el siglo XX de la gran domesticación operada a lo largo del siglo XIX, de las poblaciones rurales al trabajo industrial. El mismo proceso de racionalización de las fuerzas productivas que se desarrolló en el siglo XIX en el sector de la producción halla su culminación en el XX en el sector del consumo... Producción y consumo, se trata de un solo e incluso gran proceso lógico de reproducción ampliada de las fuerzas productivas y de su control" (Baudrillard. 1970: 115-6, cursivas en el original). De este modo, producción y consumo son las dos caras del gran proceso lógico en la reproducción expandida del sistema capitalista y de su control de la producción y la reproducción social.

Por otro lado, el consumo, refuerza la disciplina del trabajo, pues más allá de la subsistencia, el consumo impele a las gentes al trabajo disponible, a la contratación precaria o a la resignada espera en el reservorio del desempleo, si quieren ser capaces de alcanzar el glamuroso estatus de consumidores. Así la explotación y el control ahora toman lugar no sólo en el área de la producción, sino también en el área del consumo. De ahí, que en vez de entender el consumo como práctica subordinada al racional arbitrio de los deseos del consumidor, Baudrillard lo ve como otra área de la vida social implementada y controlada por el sistema productivo. Por ello, el consumo no es un lugar de libertad, sino el locus de la dependencia radicalizada. Respecto a sus aportes teórico-metodológicos, cabe decir que, independientemente al reconocimiento que de su obra hacen sus amigos americanos (Douglas Kellner y Fredric Jameson), existe una cierta ingratitud hacia Baudrillard, a pesar de que mucho antes que se certificase el ocaso de la "filosofía de la conciencia" y de que el pensamiento científico social efectuase el "giro lingüístico", su gesto metodológico constituyó una verdadera anticipación al implementar en sociología el método de la lingüística estructural, para fundamentar que signo y mercancía han venido a producir juntos el "artículo-signo" (1970. 1972), aceptando la premisa derivada del 
estructuralismo de que los significados culturales están sujetos a una lógica diferencial de oposición entre los distintos (objetos) significantes.

En consecuencia y, mientras para J. Lacan el "inconsciente está estructurado como un lenguaje"(1966), para Baudrillard, la sociedad de consumo contemporánea está estructurada a través del lenguaje de los artículos-signo: "Es un punto fundamental para la definición del consumo entenderlo: 1/ no más como una práctica funcional de los objetos y de su posesión; 2/ tampoco más por la simple función de prestigio individual o de grupo; 3/ y sí más como un sistema de comunicación e de intercambio, como un código de signos continuamente emitidos, recibidos y reinventados, como un lenguaje" (Baudrillard. 1970 : 134). El consumo, entonces, no debe entenderse como el consumo de valores de uso, una utilidad material, ni siquiera en términos del valor de cambio (precios), sino fundamentalmente como consumo de "signos", entendiendo el objeto-signo en el sentido lingüístico estructural de Saussure, esto es, con un significado arbitrariamente determinado por su posición en un autorreferencial sistema de significantes (el resto de objetos-signos).

Una de sus tesis fundamentales es que para el capitalismo de consumo, en aras a maximizar su rentabilidad, es más interesante potenciar los deseos de posesión de objetos-signos en los consumidores, que definir la articulación entre producción y necesidades (sobre todo las de subsistencia, por su escasa o nula rentabilidad). De este modo, el proceso motivacional de la sociedad de consumo comandado por la oferta (primero por la producción, que crea diversos segmentos para un mismo producto, al tiempo que un diseño diferencial para cada uno de ellos; diferencias que, a su vez, incentivarán las prácticas de publicidad y marketing), pasa antes por la potenciación de los deseos de necesidades superfluas (sin valor de uso), las propiamente sígnicas, las cuales remiten a una significación relativa a la ubicación y a la reproducción de la estratificación social. Así, dichas "necesidades ociosas" son constituidas por los estrategas y decisores que al servicio del poder (de la oferta) 
diseñan una cultura de masas con el objetivo de modelar la conducta del consumidor a través de las prácticas antedichas. Baudrillard arguye que no deberíamos interpretar las necesidades simplemente como la generación de las necesidades de productos específicos, por parte de la oferta industrial. Lo que se crea más bien es la "necesidad de necesitar", el "deseo de desear": "Tomad vuestros deseos por la realidad puede llegar a entenderse como un eslogan desesperado del poder" (Baudrillard. 1978b : 47).

Por tanto, en la sociedad de consumo, la interacción social está regida por la soberanía de los artículos-signos. Por ello, los consumidores consumen, no tanto objetos específicos para cumplimentar fines concretos (cubrir necesidades primarias, gozar de la utilidad funcional de los objetos), sino que el consumo que verdaderamente cuenta para la "producción y reproducción social" es aquél que implementa en los objetos un "plus valor simbólico", es decir, que incorpora una validación de prestigio, riqueza y poder de estatus que su posesión confiere. Pues por encima de la satisfacción de la necesidad, el consumo posee un rol de instrumento para la jerarquía social que cristaliza en el valor simbólico de los objetos (convertidos así en vehículos de producción social de diferencias y valores clasistas). Rol imprescindible para la producción/reproducción de la estratificación social.

En consecuencia, la ideología hedonista que sustenta el consumo no es sino la coartada de un vector más fundamental, la lógica de la diferenciación social. Pues, la carrera hacia el consumo y la incesante avidez de novedades no encuentran su fuente en la motivación del placer, sino que operan bajo el impulso de la competición entre las clases. De ahí, que la sociología del consumo de Baudrillard no se fundamente sobre una teoría de las necesidades y de su satisfacción, o sobre la ratio prestaciones y precios, sino sobre una teoría de la diferenciación social y de su significación: "Bajo su evidencia concreta, las necesidades y las funciones no describen en el fondo sino un nivel abstracto, un discurso manifiesto de los objetos, frente al cual el discurso 
social, ampliamente inconsciente, aparece como fundamental. Una verdadera teoría de los objetos y del consumo se fundará no sobre una teoría de las necesidades y de su satisfacción, sino sobre una teoría de la prestación social y de la significación" (Baudrillard. 1972 : 2).

Precisamente es la lógica del objeto-signo de estatus la que impulsa a la renovación acelerada de objetos y su reestructuración bajo el imperio del consumo, pues el fin de éste es fundamentalmente reproducir las diferencias. En este sentido, el consumo como instrumento de distinción de clases reproduce la segregación social y cultural, y participa de las mitologías modernas que mistifican una igualdad inexistente. De ahí, que la sociedad de consumo no sea más que una robusta factoría de producción de objetos que portan valores-signos, cuya función es atribuir contenidos a los distintos segmentos sociales, estableciendo así sus diferencias, en una época aparentemente igualitaria que convierte en obsoletas tanto las jerarquías del linaje (hereditarias) como las productivas (curriculares y/o profesionales). Ahora bien, en la sociedad de consumo, esta negativa de los referentes (definición normativa de las necesidades, de los valores de uso de las cosas y de su correspondencia con una equitativa distribución social de la riqueza) es reemplazada por un campo inestable de significantes flotantes, dentro de una cultura que impone su lógica metonímica, que prescinde del establecimiento de los sentidos y significados (no interesada en condensar/metaforizar), para así promover el permanente deslizamiento a través del consumo de los plurales y diversos artículos-signos, y rentabilizar más sus ganancias económicas y de colonización de las conciencias.

Así, según Baudrillard, la lógica de la cultura del consumo refuerza "la ilusión referencial" y, con ella, el colapso de todos los referentes, la soberanía absoluta del nihilismo, la anomia y el simulacro, como valores y formas propias de la lógica performativa, especular y espectacular del capitalismo tardío (Baudrillard. 1978b). Lógica que se basa en la sobreproducción de signos y la reproducción de imágenes y 
simulaciones que llevan a una pérdida de significado estable, y una estetización de la realidad en la cual las masas quedan subyugadas/fascinadas por el flujo interminable de yuxtaposiciones ininteligibles que transportan al espectador más allá del sentido estable hacia la apoteosis del simulacro y la reproducción sígnica (Baudrillard. 1978b).

Resulta entonces que, según Baudrillard, la lógica de la sociedad de consumo ha sido tremendamente eficaz en la producción de una experiencia de la realidad social que es desestabilizada por un continuo bombardeo de signos e imágenes generado por el exceso de información, por la abundancia de significados, y por un abrumador intercambio de signos y significantes $\mathrm{y}$, todo ello, reforzado por las nuevas tecnologías de la comunicación de masas. De este modo, la vida social en la sociedad de consumo (caracteriza por el vértigo, la distorsión del sentido y la producción serializada y banal de significados), se vuelve anómica, pues las relaciones sociales son más variables y menos ancladas sobre valores y normas estables. Para Baudrillard esto significa que nosotros vivimos por todas partes ya en una "alucinación estética de la realidad" y, por tanto, en el "fin de lo social", en la pérdida del suelo real, de los referentes reales (Baudrillard. 1978a : 67). "Fin de lo social", en el abrumador flujo de signos e imágenes que está empujándonos más allá de lo social, a la realidad virtual creada por los medios de comunicación (televisión, videos de rock), citados como ejemplos de pastiche, mezcla ecléctica de códigos, yuxtaposiciones extravagantes y significantes desencadenados que desafían y socavan el significado y la legibilidad del sentido de las cosas, así como la referencia y estabilidad de las prácticas sociales.

Antes de terminar, es importante señalar el criterio de Baudrillard sobre los tipos de opciones consumistas, pues en este hiperreal escenario social, dos son las prácticas sociales que, según este autor, concurren antitéticamente en la sociedad de consumo. Por un lado la de "los nuevos héroes de la cultura de consumo", que hacen del estilo 
todo un proyecto de vida y despliegan su gusto y criterio de consumo en la particularidad del conjunto de bienes, ropa, prácticas, experiencias, apariencia y disposiciones corporales, integrándose así en la estructura social por la vía de la adscripción al consumo. Pobres diablos, según Baudrillard, que pretenden compensar con la estilización de su vida el coeficiente de alienación que soportan. Mientras que, por otro lado, en un mundo post-revolucionario y post-marxista, la única forma de resistencia social que, según Baudrillard, permanece abierta es la de un consumo des-regulado o no-estructurado; un consumo sin infantilismo, ni conformismo, ni pasividad e idiotez. Consumo, por tanto, como "reacción negativa" de una "exigencia radical, de una revolución que liberaría no los objetos y su valor, sino la relación de intercambio misma, la reciprocidad de una palabra que el terrorismo del valor aplasta hoy por doquier" (Baudrillard. 1972 : 263)

\subsection{Fredric Jameson, o el consumo como ideología del capitalismo tardío.}

Jameson, partiendo de la teoría de E. Mandel (1975), ha intentado resumir en un tríptico comprensivo e interrelacionado de "modos de producción" (capitalismo de mercado, de monopolio o imperialista y multinacional), "tecnología" adecuada a cada uno de ellos (vapor, electricidad y explosión, y cibernética y energía atómica) y "desarrollos estéticos dominantes" (realismo, modernismo y posmodernismo), un "mapa cognitivo", según sus propios términos, del capitalismo tardío durante el actual periodo de transición y cambio (Jameson. 1984a : 80-1). Su propósito es menos ofrecer un relato definitivo de los significados de la transformación social contemporánea, y más describir algunos de los cambios sociales más manifiestos de los últimos años y considerar varios aspectos inherentes a la lógica del capital que pueden ser usados para comprender y teorizar aquellos cambios culturales que él identifica con el posmodernismo y con la sociedad de consumo: "Conceder alguna originalidad histórica a una cultura posmoderna es también afirmar implícitamente 
cierta diferencia estructural radical entre lo que a veces se llama sociedad de consumo y los momentos anteriores del capitalismo del que surgió" (Jameson. 1984b : $39)$.

Entre esos cambios es de fundamental importancia el de la hipertrofia y la estetización de la sociedad de consumo: "Creo que la emergencia del posmodernismo está estrechamente relacionada con la de este nuevo momento del capitalismo tardío consumista o multinacional", caracterizado, entre otras cosas, por "nuevos tipos de consumo; obsolescencia planificada, un ritmo cada vez más rápido de cambios en la moda y los estilos; la penetración de la publicidad, la televisión y los medios en general a lo largo de toda la sociedad en una medida hasta ahora sin paralelo; el reemplazo de la antigua tensión entre el campo y la ciudad, el centro y la provincia, por el suburbio y la estandarización universal; el desarrollo de las grandes redes de supercarreteras y la llegada de la cultura del automóvil. Éstos son algunos de los rasgos que parecerían marcar una ruptura radical con la sociedad de la preguerra en que el alto modernismo todavía era una fuerza subterránea" (Jameson. 1988 : 37).

Pero, según Jameson, el consumo no sólo consiste en un mayor y mejor acoplamiento entre la disponibilidad de la oferta y la avidez de la demanda, sino que constituye, por la vía de la estetización general de la vida cotidiana, un poderoso dispositivo de legitimación que, de forma opaca y mistificada, opera como ideología del capitalismo tardío. Tal estética consumista posmoderna se caracteriza porque invita a una fascinación, más que a una contemplación de sus contenidos; porque celebra las apariencias y la superficie de las cosas, soslayando la búsqueda de profundidad o de significado oculto o latente (como el modernismo); pone en primer plano la materialidad y la discontinuidad entre los significantes, mientras disuelve las posibilidades hermenéuticas del significado; y deja la distinción crítica entre formas de "alta cultura" y cultura popular obsoleta (Jameson. 1984a : 21-22 y 33-34). En suma, la estética consumista postmoderna, en vez de preocuparse y ocuparse por la 
recepción contemplativa e interpretación cognitiva de los contenidos culturales, los transforma y adecua para su consumo inmediato. Por ello, el postmodernismo es considerado por Jameson como la superestructura estético-cultural del nuevo ethos consumista que impone el capitalismo tardío.

Como bien puede apreciarse, la concepción de Jameson de la cultura posmoderna está influenciada fuertemente por el trabajo de Baudrillard (Jameson. 1989 : 56; Jameson. 1998 : 242). Sin la causticidad apocalíptica y corrosiva de Baudrillard, él también visualiza la cultura posmoderna como la cultura de la sociedad de consumo; y, en continuidad con la tesis del sociólogo francés de una "hiperrealidad" basada en la serialización, repetición y el simulacro, Jameson afirma que la lógica cultural posmoderna es la que mistifica, extiende y refuerza el consumo. Así, mientras que: "el modernismo funcionó contra su sociedad de una manera que se describe diversamente como crítica, negativa, contestataria, subversiva, opositora y cosas por el estilo,... el posmodernismo copia o reproduce -refuerza- la lógica del capitalismo consumista" (Jameson. 1988 : 38).

Esta proliferación de signos, copias, imágenes y espectáculos, también entraña una diferencia fundamental entre el posmodernismo y las anteriores etapas culturales, la desaparición de la distinción entre las diferentes culturas (tradicionales, elitistas o masológicas), la aceptación de la validez de la cultura del cine de clase B, las series kitsch de televisión y la cultura del Reader's Digest", por encima de los textos de un "Joyce o un Mahler" que, incluso: "los incorporan, a punto tal que el límite entre el arte elevado y las formas comerciales parece cada vez más difícil de trazar" (Jameson. 1988 : 16-17). Por eso, según Jameson, es evidente que la lógica inmanente del capitalismo financiero lleva al acentuamiento de la sociedad de consumo y ésta, a su vez, implementa el posmodernismo cultural. Además, según Jameson, es "la ideología del consumo" el más robusto aparato de legitimación del capitalismo tardío, por eso puede prescindir de teorías que justifiquen su legitimidad. Y por eso 
también han caído los valores morales "modernistas" de libertad, igualdad, fraternidad, para emerger los del fragmento, lo heteróclito, lo aleatorio, el pastiche y el simulacro (Jameson. 1984a : 61).

Jameson, al igual que Baudrillard, lejos de considerar los bienes meramente como utilidades que tienen un valor de uso y un valor de cambio, que pueden relacionarse con algún sistema fijo de necesidades humanas, sitúa el acento en el valor del artículo como signo, lo que ha llevado a enfatizar el papel crucial de la cultura del consumo en la reproducción del capitalismo contemporáneo. Ninguna sociedad se ha saturado alguna vez con signos e imágenes como ésta, en la que la publicidad, la decoración y el despliegue de objetos en los "mundos de ensueños" de las grandes superficies comerciales juegan sobre la lógica del artículo-signo, transgrediendo los significados tradicionales y creando yuxtaposiciones sorprendentes y nuevas, que eficazmente redefinen las mercancías y refuerzan su consumo. Por tanto, de forma permanente los bienes de consumo cotidianos se asocian con el lujo, lo exótico, la exaltación de la belleza y del flirt, etc., dejando de lado su arcaico uso funcional, cada vez más difícil de definir. Así, mientras el fordismo puede considerarse un régimen de acumulación y de consumo necesario, el post-fordismo posmodernista se convierte, según Jameson, en un régimen de reconversión industrial, producción de nuevas tecnologías electrónicas e hiperconsumo, sobre todo, de necesidades ociosas.

Por eso y, aunque su preocupación central es la teoría de la cultura y del arte, Jamenson concluye sus obras animando a continuar el análisis de Marx, sobre las transformaciones del capitalismo, situando el foco de atención en el capitalismo financiero y de consumo que, con carácter globalizador, extiende sus tentáculos por el espacio multinacional. Este es el reto que, según él, tiene que aceptar el marxismo: "para que elabore un análisis verdaderamente materialista del consumo de mercancías así como de las rivalidades grupales de la lucha por el reconocimiento 
(consumismo y guerras civiles étnicas) que en conjunto caracterizan nuestra era". (Jameson. 1998 : 125)

\subsection{Zygmun Bauman, o el giro desde la "ética del trabajo a la "estética del consumo".}

Nacido en Polonia, Z. Bauman ha impartido sociología en un gran número de universidades, incluyendo Tel Aviv, antes de llegar a ser profesor de sociología en la Universidad de Leeds. Su contribución más importante es el intento de crear una sociología postmoderna, a partir de la crítica a las diversas nociones "modernas" de lo social. Bauman, siguiendo el criterio durkheimiano de la "solidaridad orgánica", desarrolla la tesis de que la noción de lo "social" emerge con la modernidad, basándose en un ordenamiento político de la población (democracia, separación de poderes y derechos y libertades ciudadanas) y, sobre todo, en una ética del trabajo, que permitió organizar la sociedad en torno a una comunidad moral integrada en torno a los valores y normas de la producción industrial.

De este modo, el trabajo no sólo era la garantía de supervivencia, sino que, además, se convertía en el eje de la vida individual y colectiva, mientras que era inherente a la pobreza el estigma de la pereza. Esto ha permanecido así hasta el postfordismo, pues hasta hace poco tiempo el Estado del bienestar se preocupaba de aquellos que no tenían ubicación en la estructura productiva, pues la cohesión social era un valor preciado y porque la cultura del trabajo creaba vínculos comunitarios (asociaciones gremiales y profesionales) y políticos (sindicatos). Pero en las sociedades postfordistas, el giro del capital hacia la tecnologización ciberelectrónica de la producción, ha permitido aumentar la productividad a costa de reducir la fuerza de trabajo, aumentando el desempleo crónico y estructural y la precarización laboral (mayor flexibilidad del mercado de trabajo, contratación temporal, etc.); y, unido a todo esto, se ha profundizado en la tendencia a jibarizar al Estado de bienestar, en base a las políticas neoliberales que difunden la idea de que más vale dinero en el 
bolsillo para consumir (menos impuestos) que políticas redistributivas (más impuestos) con las que paliar el downsizing (el achicamiento o reducción de personal. Bauman. 1998 : 45).

Por eso, en la modernidad tardía, asistimos a una significativa sustitución de lo social. En otras palabras, los lazos universales que vinculaban a las gentes en torno al trabajo y al consumo para cubrir las necesidades de supervivencia, son cuestionados por una norma social que impone "la obligación de consumir", porque en ello reside la estrategia de maximización de rentabilidad del capital: "En su etapa presente de modernidad tardía -esta segunda modernidad, o posmodernidad- la sociedad humana impone a sus miembros la obligación de ser consumidores. La forma en que esta sociedad moldea a sus integrantes está regida, ante todo y en primer lugar, por la necesidad de desempeñar ese papel; la norma que les impone, la de tener capacidad y voluntad de consumir" (Bauman. $1998: 44$ ).

En consecuencia, la actual sociedad es una "comunidad de consumidores", en la misma medida en que las sociedades de nuestros abuelos eran "sociedades de productores". Por lo tanto, lo social ha sido sustituido por un individualismo cautivo de su acceso a los distintos corolarios placenteros que les promete el mercado. De este modo, el consumo llega a ser el nuevo centro de una socialidad individualizada que hace del "consumo la experiencia cumbre de su autorrealización" (Bauman. 1997 : 179); y que subordina todo tipo de discurso cultural al de una cultura de masas consumista, creada por empresarios y estetizada por los dispositivos de la publicidad y el marketing. Por eso hoy asistimos a la sustitución de la "ética del trabajo" por la "estética del consumo". La norma social ya no la marca el mundo del trabajo con sus valores de esfuerzo, disciplina y solidaridad comunitaria, sino los consumidores dispuestos a dejarse fascinar y seducir. 
Pero no todos los individuos que aspiran a estar integrados en la sociedad de consumo lo consiguen. Aquellos que no lo logran (los desempleados, los pobres y marginados etc.) son considerados como "consumidores defectuosos/frustrados", gente ordinaria que hicieron las elecciones equivocadas a la hora de adaptarse al canon social del consumo: "Los pobres en la sociedad de consumo no tienen acceso a una vida normal; menos aún a una existencia feliz. En nuestra sociedad, esa limitación los pone en la condición de consumidores manqués: consumidores defectuosos o frustrados,... imperfectos, deficientes; en otras palabras, incapaces de adaptarse a nuestro mundo" (Bauman. 1998 : 64).

Esto conlleva cambios significantes en la estructura social, pues al gravitar el principio de integración social sobre el cumplimiento de la actitud (de libertad de elección y disponibilidad deseante. Bauman. 1998 : 47) y la conducta del consumidor ideal (capacidad adquisitiva destinada al consumo, entendido como vocación de vida. Bauman. 1998 : 53), los comportamientos de los "consumidores defectuosos" tienen una doble marginación, pues son motivo de "exclusión social", a la vez que de "exilio interior" ante la imposibilidad de no poder cumplir con los deberes del consumidor (Bauman. 1998 : 64-65). Y en esto consiste, para Bauman, el nuevo y potente dispositivo de dumping social que genera la sociedad de consumo, pues para consumir se necesita dinero, capacidad de elección y disposición deseante. Mientras que los pobres no tienen capacidad adquisitiva ni libertad de elección, con lo cual su destino es la marginación, al estar cada vez más en crisis tanto el Estado de bienestar, como sus instituciones reeducativas que orientaban sus actividades hacia la reinserción laboral.

\subsection{Michel de Certeau, o el consumo como subversión.}

Michel de Certeau es quizá el único autor, dentro de esta perspectiva, que concede peso especifico a la agencia de la demanda, alejándose, por tanto, del tópico de unos 
consumidores pasivos y subalternos al proceso de manipulación por parte de la oferta, pues, según la perspectiva libertaria de De Certeau, el consumo posibilita una cierta revancha de los débiles sobre los fuertes. De Certeau parte de la crítica a los habituales estudios sobre el consumo, que al centrarse exclusivamente sobre la mensuración e inventariado de los hábitos de consumo, obvian adentrase en el "enigma" que plantea el consumo como práctica social: "Los estudios sobre el consumo se centran en estudiar lo que se vende, cuánto tiempo se ve la TV, qué se consume, pero soslayando siempre lo que sucede una vez que algo se ha comprado o se ha visto. Pero, la pregunta crucial es ¿qué hace el consumidor con lo que ve, absorbe, recibe o compra?. Esto es, hay que preguntarse y responder en qué consiste el enigma del consumidor" (De Certeau 1984 : 164).

Enigma que De Certeau explica, tomando de la obra de Clausewitz la metáfora del "estado de guerra", para describir el permanente toma y daca entre la oferta y la demanda. Para este autor, la oferta productiva es la fuerza militar dominante, con dinero para financiar a técnicos y expertos (marketing y publicidad) que le proporcionan "estrategias", destinadas a determinar la conducta consumidora, en función de la maximización de sus beneficios. Pero como cualquier ejército convencional grande, tiene contradicciones propias (es obstaculizado por la inflexibilidad general proporcional al tamaño de sus ambiciones); y, además, tiene que sufrir el contencioso de la "guerra de guerrillas" empleada por los consumidores, con sus maniobras de velocidad, las astucias engañosas, la re-torsión del consumo en beneficio propio, etc., en definitiva, las "tácticas" de resistencia a los intereses de la oferta, en el campo de batalla que constituyen los espacios propios de la cultura del consumo. Por eso: "salir, hablar, leer, comprar y cocinar son actividades propias de las astucias tácticas: trucos afilados de los "débiles" contra el orden de analfabetismo y adocenamiento impuesto por los "fuertes", un arte de sobreponerse al adversario con argucias de cazador, movilidades polimórficas, maniobrabilidades, descubrimientos jubilosos, poéticos y guerreros" (De Certeau. 1984 : 171). 
En suma, "The Practice of Everyday Life" (1984) es todo un manual de batalla, que intenta desmontar el habitual cliché de un consumidor construido ad hoc por la oferta, para ulteriormente desarrollar una teoría emancipativa, comprensiva del reservorio de tácticas subversivas, creativas y "generadoras de poder" (empowering); y, por si esto fuera poco, además, intemporales, pues, según De Certeau, estas tácticas de resistencia: "Constituyen un arte sin edad, que no sólo ha persistido a través de sucesivos órdenes políticos, sino que... forma parte de las "extrañas alianzas", que han precedido a las fronteras de la humanidad, pues se remonta hasta los peces y plantas prehistóricas que, para sobrevivir, realizaban trucos de camuflaje" (De Certeau. 1984 : 171-172).

\section{Perspectiva anfibológica: el consumo visto como "el encanto de un mundo desencantado"}

Una segunda constelación de autores es la compuesta por los anfibológicos o mesocráticos, los del término medio, que no atribuyen al consumo ni la salvación a través de la satisfacción de los deseos, ni la perdición en el infierno de la manipulación y la alienación. A pesar de sus diferencias, tienen en común la atención hacia el individuo y sus adscripciones grupales (grupos de estatus, grupos de pertenencia y de referencia), en tanto que prácticas y estilos de vida de consumo significativo; y en cómo se relaciona todo esto con la estructura social en la que se encuentran dichos individuos y grupos y en la que se inscriben las citadas prácticas. Para esta visión y, dentro de la dimensión metodológica, el rol del consumo, al margen de su función económica, se manifiesta como un óptimo descriptor para diferenciar los distintos grupos sociales y sus correspondientes estilos de vida; y, además, constituye un indicador básico de "calidad de vida", necesario para evaluar el bienestar y la movilidad social alcanzada por las personas en una sociedad dada. 
Dentro del plano evaluativo, los diversos autores de esta perspectiva, a pesar de sus diferencias, mantienen un tratamiento anfibológico del consumo, al considerarlo simultáneamente como una práctica que se impone socialmente al individuo por la vía de la socialización, y que configurará sus gustos y hábitos; mientras que, por otra parte, el consumo, sobre todo el de bienes simbólicos, se considera positivamente, pues tiene por resultante la generación de unos estilos de vida autónomos, expresivos y realizativos, que hacen más habitable y emancipada la existencia personal y colectiva. De ahí que, para Simmel y Weber, se convierta incluso en toda una teoría alternativa a las consecuencias negativas de la modernidad industrial. Formas de vida inauténticas, instrumentales, masificadas y cosificantes, que a principios del siglo XX vinieron a conformar la temática del "malestar en la cultura", cuestión que, para José Enrique Rodríguez Ibáñez (2000), aún sigue candente en nuestros días. A continuación vamos a recorrer el itinerario de las obras de Simmel, Weber, Benjamin y Bourdieu.

\subsection{George Simmel, o el consumo como pertenencia y distinción.}

Recientemente J.M. Marinas ha destacado la importancia de George Simmel para la sociología del consumo. Su argumento central es que Simmel aporta a la sociología toda una teoría sobre el consumo, que irradia en tres direcciones: la vectorialización de la dinámica económica en la doble vertiente de la lógica monetarista del dinero y la lógica del fetichismo de la mercancía; un primer análisis de las nuevas metrópolis y sus nuevos centros comerciales; y el impacto de todo esto en la constitución de la identidad social en los comienzos de siglo (J.M. Marinas. 2000 : 184). Y es que Simmel fue un pensador atípico, un extraterritorial del pensamiento, que de forma independiente y libre desarrolló un corpus teórico muy variado en el que existen ciertas líneas temáticas constantes, entre las que destaca "la ambivalencia" endémica de todo fenómeno social (precursora de la teoría del "doble filo" de la modernidad de Giddens 1990). Pues, según Simmel, la vida social está hecha no sólo de 
ambigüedades, sino de dualidades antónimas, a las cuales es difícil substraerse. Sigamos sus obras más importantes donde ejemplifica su comprensión de la vida social entendida como relación dual y antitética, y en donde siempre aparece el consumo como auténtico centro de la vida social.

Así, en "La filosofía del dinero" (1900), éste se ha convertido un fenómeno social ambivalente: por un lado positivo, pues ayuda a "personalizar" la vida socioeconómica, liberando de los lazos comunitarios tradicionales que presiden el trueque en términos del valor de uso, y permitiendo el desarrollo de la individualidad y la personalidad, así como de los estilos de vida diferenciales, por el enriquecimiento global de la sociedad monetarizada. Pero, al mismo tiempo, "despersonaliza" (cosifica y aliena), al generar relaciones interesadas e impersonales entre las gentes, es decir, las agrega y masifica en el conglomerado de la circulación monetarista propia del nuevo modelo societario de la "sociedad anónima". Con la autonomización del dinero (cuyas monedas son redondas, simbolizando con ello su óptima circulación), aumenta el flujo de productos, uno de cuyos cometidos es proporcionar signos externos a los nuevos segmentos sociales que surgen con la segunda revolución industrial. Circulación de mercancías, que posibilita el desarrollo de la gran ciudad (Simmel. 1903) y, con ello, la creación de los grandes centros comerciales, que potencian la viabilidad de la moda y con ella, el carácter móvil del mundo social, el cambio permanente, la fugacidad de la vida moderna.

De este modo, la confortable atmósfera de la Gemeinschaft, donde todo el mundo conoce a todo el mundo, ha sido sustituida por la vertiginosa e impersonal Gesellschaft, donde nadie conoce a nadie en el torbellino de extraños siempre en movimiento. En consecuencia, los fenómenos negativos de la alienación y el fetichismo se trasladan de la esfera de la producción al ámbito del consumo. Pues, para Simmel, ya no se trata, por tanto, de la alienación del individuo en el trabajo, 
como lo teorizara Marx, de su incapacidad para captar el proceso total de la producción debido a la cada vez más compleja división social del trabajo, sino de analizar la alienación producida por el consumo masivo de artículos. Pues, según Simmel, la personalidad desaparece (se aliena) cuando ya no se produce para un cliente concreto, sino para un comprador desconocido y masificado, cuando ya no se media entre vendedor y comprador, sino que esta mediación es sustituida por una impersonal y anónima compra por parte del consumidor dentro de unos "grandes almacenes".

En el ensayo sobre "La moda". (1895 : 27 y ss.), Simmel desglosa este fenómeno sociocultural en dos tendencias antónimas que actúan simultáneamente: la "imitación" o igualación social y la "diferenciación" individual o el cambio. Donde la "imitación" deriva de una herencia sociopsicológica de la influencia del grupo sobre la vida individual, proporcionándole apoyo social y sentido de pertenencia; mientras que la tendencia hacia la "diferenciación", que es la que habitualmente crea moda, nace al arbitrio del "individualismo de la distinción". Por ello, nos dirá Simmel: "La historia de la sociedad podría reconstruirse a partir de la lucha, el compromiso, las conciliaciones lentamente conseguidas y rápidamente desbaratadas que surgen entre la tendencia a fundirnos con nuestro grupo social y a destacar fuera de él nuestra individualidad" (G. Simmel. 1895 : 27). En el plano individual, también la moda tiene una doble función: anular la subjetividad, anegándola en una reproducción mimética respecto a un canon que no ha diseñado el portador de la misma. Pero también hace de "máscara" tras la cual puede ocultarse el individuo para mantener un espacio íntimo de libertad y de autonomía en el que realiza su propia voluntad. Con ello reconoce y libera aspectos individuales diferenciadores.

Simmel ve la sociedad en general, y no solamente la moda en particular, en una forma dualista. Hay una tensión entre un principio de generalización y un principio de especialización. De este modo, el consumo produce similitud, unión y solidaridad 
con el grupo de pertenencia y la simultánea segregación y exclusión de todos los otros. Pero para Simmel, anticipando el proceso de imitación vicaria señalado ulteriormente por Veblen, los grupos sociales bajos y medios desean ascender en la escala social, desean parecerse a los grupos por encima de ellos en dicha jerarquía: "Las modas son siempre modas de clase, de manera que las modas de la clase alta se diferencian de las de la clase inferior y son abandonadas en el momento en esta última empieza a acceder a ellas" . (Simmel. 1895 : 29). El ensayo de G. Simmel sobre la moda, según Peter Corrigan (1997 : 169), es una temprana articulación de lo que más tarde se conocerá como la "teoría del goteo" (trickle-down) de la difusión de la moda. Corrigan apunta que el término "trickle-down" es quizá una expresión equívoca, pues no es que la moda gotee hacia los grupos inferiores, pasivamente receptores, sino, más bien, que estos últimos son los que buscan activamente imitar a los grupos superiores, forzándoles al cambio. Ahora bien, la observación de Simmel de que la dinámica del consumo y de la moda es tal que su popularidad y expansión lleva a crear un nuevo horizonte cultural en el que consumo y moda se autonomizan (como un descriptor más de la "tragedia de la cultura") constriñendo a la subjetividad epocal, sugiere que necesitamos examinar más de cerca los procesos sociales que actualmente estructuran nuestros gustos y criterios sobre el consumo y la moda.

En suma, Simmel, al igual que más tarde Weber, considera que el mundo se iba convirtiendo en una "jaula de hierro" de la cultura objetiva, jaula de la que las personas tendrían cada vez menos posibilidades de escapar. Por tanto, y frente al totalizante dominio de una kultur moderna (la cultura objetiva de las producciones humanas objetivadas, que impone unos valores exclusivamente materiales e instrumentales, de los que el dinero es el epítome y el consumo su derivado), sólo quedaba, para Simmel, la posibilidad de la afirmación de la cultura individual "estilizada" (capacidad del actor para producir, absorber y controlar los elementos de la cultura objetiva, del disenso subjetivo sostenido por la convicción en principios y valores, en consonancia con el carácter propio, y salvaguardados por la bildung 
propia de la burguesía ilustrada, esto es, por un sentido subjetivo de la "distinción" personal que, pivotando sobre la virtud y la excelencia, pudiese contribuir a reinstitucionalizar unas formas de vida más valiosas y habitables). Esto es lo que le convierte en el primer teórico del estilo de vida (cuyo centro es "el carácter centrípeto espiritual de la vida". Simmel. 1900 : 611) como alternativa sociopsicológica a los procesos sociales de alienación y cosificación mencionados. Su relevo lo tomará, como veremos a continuación, Max Weber. Por último, si el estilo de vida es la alternativa sociopsicológica a nivel de los individuos y los grupos, la sociología del arte será para Simmel el conocimiento más adecuado para dotarle de sentido. De ahí, el doblete de la teoría sociológica simmeliana: una "sociología del arte" como fundamento de su teoría sociopsicológica de una acción entendida como "estilo de vida". Doblete que le convierte en un adelantado heraldo de la teoría sociológica de la postmodernidad.

\subsection{Max Weber, o el consumo como estilo de vida de la personalidad valiosa.}

Weber, como antes Tönnies y Simmel, contempla el amanecer de la rápida industrialización moderna con una profunda ambivalencia (consciente de las "consecuencias indeseadas de la acción") más que como un primer paso hacia una nueva era de progreso. Así, mientras daba cautamente la bienvenida a las posibilidades que ofrecía para el nuevo tipo de individualismo emergente (sellando el fin de las cadenas feudales del pasado), consideraba que la modernización socavaba las pocas referencias guía, mediante las cuales el "hombre moderno" podría establecer un sentido y un significado para su vida o incluso su acción cotidiana. En pocas palabras, podría decirse que el tema central de su programa de investigación es el estudio del impacto de los órdenes de vida sociales y culturales en la personalidad y en los estilos de vida de su tiempo; y viceversa, en cómo la subjetividad intentando primero replegarse y luego recomponerse, daba sentido y 
significado a su acción, siendo capaz de incidir en los órdenes, procesos y estructuras sociales.

En consecuencia, el gran "adversario" de la teorización weberiana son las consecuencias socioculturales negativas del proceso de modernización. Pues, frente al poder de la racionalidad instrumental, la burocratización y la masificación, Weber pensaba que la única contra-fuerza capaz de entender y apoyar el ya tenue carácter del sentido de la existencia, era la del proceso de estilización de la vida, llevado a cabo por la "personalidad valiosa" (persönlichkeitsbegriff), que tomando lo mejor de las formas de vida de los estamentos sociales tradicionales pudiese "estilizar su vida", antes que el "politeísmo de los valores" y "la separación de esferas sociales" motivada por la modernización, hiciesen olvidar el sentido y el valor de la distinción personal y social encarnadas en dichas formas de vida estamentales.

Weber, apoyado por sus estudios de sociología de la religión (averiguando los diferentes sentidos y valores propios de los ethos de cada una de las grandes religiones), así como los de sociología histórica comparada sobre civilizaciones premodernas y no occidentales, había investigado los distintos tipos ideales de estilo de vida que, relacionados con formas de vida y tipos de liderazgo, ofrecían las pistas para conceptualizar la noción de estatus. Así, a través del estudio de los diferentes estilos de vida estamentales, Weber encuentra la explicación de por qué, en cada etapa histórica, la acción social era pautada por los diversos grupos de estatus, los cuales, al ser representantes del éxito político, social y cultural, y garantes de un determinado ethos religioso, configuraban dicha acción imponiendo sus sentidos y significados de estilo de vida, así como sus metamorfosis a lo largo de la historia.

En consecuencia, va a ser su definición de estatus la que dará pie a la de estilo de vida, pues Weber define los grupos de estatus estructurándolos según los principios de su consumo de bienes en las diversas formas específicas de sus maneras de vivir o 
estilos de vida: "Simplificando las cosas tal vez de un modo excesivo, se podría decir: las clases se organizan según las relaciones de producción y adquisición de bienes, los estamentos, según los principios de su consumo de bienes en las diversas formas específicas de su 'manera de vivir'" (Weber. 1922 : 692). Y esta oposición de los estilos de vida estamentales al modo racional de vida (rationale lebensführung) que constituye el "standard of life" del modo metódico de vida (methodische lebensfürung), va a proporcionar a Weber las bases para elaborar una teoría psicosocial de una "personalidad valiosa" que orienta su acción hacia la "estilización de la vida" (stilisierlung des lebens), a partir de la cual poder modelar y construir la acción como tarea ética, esto es, recomponiendo el sentido y significado tanto de la experiencia del yo, como de las vivencias comunitarias primordiales, desecadas con el advenimiento del proceso de modernización (Soldevilla. $1998: 23$ y ss.).

En este contexto de la teoría weberiana de la stilisierlung des lebens, el consumo de bienes se convierte en inversión sustantiva para el estilo de vida, por que desempeña un papel decisivo del criterio de la "personalidad valiosa", la cual tiene a bien dirigir su destino a través de las "acepciones personales" (consistencia interior, juicio, gusto, ética de la existencia y sentido de dignidad por la pertenencia al grupo de estatus), opuestas a los convencionales criterios de evaluación económica, y que como referencia regulativa rigen los estilos de vida de los diferentes grupos de estatus: "Toda 'estilización de la vida', cualesquiera que sean sus manifestaciones, tiene su origen en la existencia de un estamento o es conservada por él... Como hemos visto, el mercado y los procesos económicos no conocen ninguna 'acepción de personas'. Dominan entonces sobre la persona los intereses 'materiales'. Nada sabe del 'honor'. En cambio, el orden estamental significa justamente lo inverso: una organización social de acuerdo con el 'honor' y un modo de vivir según las normas estamentales" (Weber 1922 : 691). 
En suma, Weber no sólo desarrolla una teoría de la estratificación social basada en los criterios de gusto y diferenciación entre los distintos grupos sociales y ocupacionales, que facilitará los ulteriores programas de investigación de W. Benjamin y P. Bourdieu; sino que, además, despliega una teoría psicosocial de la acción frente a las consecuencias negativas de la modernización sociocultural, en la que una "personalidad valiosa" tiene que orientar su acción hacia el "estilo de vida". De ahí, que la relevancia de las prácticas de consumo, en Weber, siempre tengan como horizonte la estilización de la vida. Por otro lado y, extrapolando el análisis weberiano a nuestros días, cabría decir que las consecuencias negativas del actual proceso tardomoderno, dificultarían, pero no impedirían, el logro de una personalidad y una comunidad de vida estilizadas. Esto es lo que subyace en las propuestas de R. Bellah (1985) y, sobre todo, de A. Giddens (1991.1992).

\subsection{Walter Benjamin, o el consumo postmoderno del flâneur.}

Walter Benjamín, heredero del legado de Simmel, es un autor que percibe la emergencia de la sociedad de consumo de una forma claramente anfibológica. De esta manera, siguiendo el argumento de Susan Buck-Morss (1989), Benjamin en su primera etapa entiende las condiciones del capitalismo industrial como un dominio de la mistificación alienante y, a la vez, como un momento del despertar colectivo; toma en serio la cultura de masas, pero no como el imperio de la falsa conciencia, sino como fuente de energía colectiva capaz de superarla (Buck-Morss. 1989 :279); por otro lado, verá en la súbita popularidad del fenómeno de la moda el fin de la dependencia y de la determinación social del linaje, la más sutil irreverencia frente a las formas tradicionales, la extensión del atractivo y el confort a las clases bajas, la celebración de la juventud y, con ello, la posibilidad de la vía dulce hacia el cambio social. Sin embargo, en su segunda etapa, especialmente en la década de 1930, coincidiendo con el incremento de su pesimismo, encuentra en el consumo y en la moda la explicación de la alienación, el fetichismo, el sutil adocenamiento 
socializador y, con todo ello, la ausencia de las condiciones de posibilidad para el anhelado cambio social (Buck-Morss. 1989 : 114-115).

En consecuencia, Benjamin nos ha legado el primer inventario sociológico de la cultura del consumo del primer tercio del presente siglo XX, con su descripción de las nuevas metrópolis y sus centros comerciales, caracterizados por él como espacios de la "fantasmagoría", auténticos "mundos de ensueño" (Buck-Morss. 1989 : 98 y 102). Inventario que compatibiliza una defensa de los mundos de vida que abre esta compuerta del consumo (ilusiones y ensueños de un anhelo de completitud potenciado por la introducción de un plus valor simbólicos en los artículos de consumo, presente en el diseño, en su representación publicitaria, y amplificado todo ello en los escaparates comerciales), y una crítica a los nuevos procesos que inaugura la cultura del consumo: mercantilización, monetarización y marginación social.

La inmensa imaginería (a la vez imaginativa e imaginaria) de los bienes desplegados en los escaparates, constantemente renovados, es presentada como el fruto de un capitalismo ávido de ofrecer novedades y diferentes estilos de vida, para así combatir tanto las crisis de sobreproducción, como para aguar la lucha de clases, segmentando el dualismo antónimo de las identidades sociales enfrentadas (burguesía vs trabajadores). Imaginería comercial destinada a la provisión de imágenes de completitud y de ensueño, y que Benjamin caracteriza como "alegoría", entendiendo por tal la manera en que un significado estable y jerárquicamente ordenado se disuelve, para acentuar la percepción de los fragmentos calidoscópicos resistentes a cualquier interpretación coherente de lo que simbolizan. En este mundo de alegorías consumistas propuestas por los escaparates de los grandes almacenes, junto a los bulevares, la arquitectura urbana que concentra en el centro de la ciudad los espacios comerciales, el río de personas que se pasean a través de estos espacios, suscitan en el paseante ilusiones y anhelos de posesión, en los cuales los objetos aparecen divorciados de su contexto y sujetos a conexiones misteriosas que son leídas según 
las expectativas de cada uno. Universo, por tanto, en el que la vida cotidiana de las grandes ciudades y sus comercios se estetiza. De ahí la expansión de ocupaciones como la arquitectura, la publicidad, el diseño industrial y la decoración, para producir un nuevo paisaje urbano estilizado a través de la impronta del "modernismo".

Benjamin, siguiendo la estela de los estudios de Simmel sobre "Las grandes urbes y la vida del espíritu" (1903) y de Weber sobre "La ciudad" (1921), reflexiona sobre la influencia de las grandes ciudades en la constitución del urbanita moderno. La metrópolis no es meramente el punto focal de la economía del dinero, es además la intersección de círculos y redes sociales de la división de trabajo, que posibilita la autonomía y libertad del individuo, a la vez que ámbito de la masificación, anonimato y alienación de los individuos y sus fragmentarias imágenes de las cosas. Grandes urbes caracterizadas por el desarrollo acelerado, la urbanización, la industrialización, la creación de una red de bulevares y de centros comerciales. La gran ciudad funciona como un inmenso laboratorio de relaciones sociales que incoa un modelo de subjetividad urbano que se convierte en el paseante solitario atraído por la multitud, por los escaparates, experto, como había anticipado Baudelaire, en el arte de gozar del "roce con la muchedumbre" a través de su propuesta de la primera identidad postmoderna que se conoce: el flâneur. Identidad tensa, esto es, diletante y trágica a la vez congratulada por el mysterium fascinans de los nuevos horizontes de experiencia existencial que se abren al urbanita de entreguerras; y, por otro lado, consciente del mysterium tremendum inherente al costado negativo de la cultura del consumo: la burda inmediatez de su formas, la sobresaturación de signos e imágenes, la disolución de los significados "personales" y "estamentales" (en el sentido de comunidad de estilo de vida), la emergencia de un bienestar romo y masificado como compensación a la severa disciplina impuesta por la organización científica del trabajo. 
Todas estas cuestiones revelan la clara anfibología de Benjamin respecto a la sociedad de consumo, que contrasta con el pesimismo de los detractores del consumo (por eso sus discrepancias con Adorno), que les conduce a rechazar el consumo como asunción vicaria de las prácticas e identidades de las clases dominantes. Reconociendo este costado negativo, sin embargo, Benjamin enfatiza el momento utópico, o positivo, de la eclosión de los bienes de consumo de masas que, de paso que proporcionaba un confort más habitable a las formas de vida populares, extendía y liberaba la creatividad del arte, que así pasaba a extenderse e implementarse en la vida cotidiana, potenciando la estilización de su existencia. Esta celebración benjaminiana del potencial estético de la cultura del consumo de masas, posee también una alta rentabilidad sociopsicológica, pues el rol del flâneur requiere, junto a sus habituales características nómadas, lúdicas y transgresivas, una notable competencia sociopsicológica para manejar su andadura en el equilibrio entre la intensa implicación y el desapego estético más distanciado.

Así, según Featherstone, el flâneur nos anticipa la actual exigencia de capacidad psicosocial para recorrer nuestros espacios urbanos, los espectáculos, los parques temáticos, las exposiciones universales, los juegos olímpicos, etc.. Paseos que requieren una notable inteligencia emocional, un "controlado descontrol" de las emociones, que sirva para disfrutar del placer, la excitación, incluso del desorden, mientras que el autodominio mantiene a distancia la natural propensión a la desmesura: "En los escritos de W. Benjamin, donde caracteriza al flâneur existe un fuerte énfasis en su disponibilidad a la sobrecarga sensorial, a las percepciones como sueños de inmersión estética de un sujeto des-centrado, en los cuales las personas se abren a un rango más amplio de sensaciones y experiencias emocionales, pero es importante también señalar que esto no supone el eclipse de los controles. Pues, se necesita disciplina y control para pasearse a través de los bienes de consumo, mirar y no arrebatarse, moverse sin interrumpir el flujo, mirar con entusiasmo controlado, y con una mirada de reojo observar a los otros sin ser visto. Tolerar la proximidad 
íntima de cuerpos, sin sentirse amenazado. En suma, moverse a través de los espacios del consumo requiere un 'controlado descontrol'" (Featherstone. 1991 : 24).

\subsection{Pierre Bourdieu, estratificación y distinción social a través del consumo.}

La investigación de Pierre Bourdieu (1979) incorpora un armazón teórico que permite entender las diferencias que pueden establecerse entre grupos o clases situando el acento en una de las dimensiones del consumo, esto es, en el matiz simbólico del consumo como práctica estratificativa, en vez de prestar atención a las relaciones de producción y propiedad como lo hace la posición marxista ortodoxa (condiciones de producción). Bourdieu retoma las tesis de Veblen (relaciones entre consumo conspicuo y estructura social) y de Simmel y Weber (consumo, moda y preferencias de estilo de vida como estrategias de distinción social), para estudiar "las bases sociales del gusto" que intervienen en los comportamientos sociales del consumo, y que implican juicios diferenciales que al mismo tiempo identifican y vuelven inteligibles y clasificables los juicios y conductas de los individuos y de los grupos sociales. De ahí que su programa de investigación tenga como centro las formas por las cuales diferentes clases consumen distintos bienes con el objetivo de expresar sus posiciones en la estructura social. Pues, en las sociedades occidentales contemporáneas, según Bourdieu, el consumo es el cañamazo a través del cual se urde la estrategia diferenciadora que permite expresar y leer el estatus social del portador de los artículos de consumo. Esto es, permite establecer estrategias de "distinción" de rango y barreras de estatus (prestigio, privilegio y poder), en base a la posesión, ausencia o escasez de los tres tipos de capital que Bourdieu analiza: el económico, el cultural y el social.

Para Bourdieu el gusto en bienes culturales funciona como un diferenciador de clase y de distinción social. Por ello, este autor busca trazar el mapa del campo social de 
los diferentes gustos en el consumo de prácticas culturales legitimadas como "distinguidas" (la visita a museos, los conciertos, la lectura) así como el gusto en los estilos de vida y las preferencias del consumo en general (comida, bebida, ropa, automóviles, novelas, periódicos, revistas, fiestas, aficiones, deportes, propuestas de ocio, etc.). En este contexto, el gusto, el juicio y el conocimiento o "capital cultural", permiten a los grupos específicos de personas entender y clasificar los bienes apropiadamente y, además, cómo usarlos, por eso se convierte en los descriptores estratificativos principales, en tanto son los que se emplean para desagregarse y distinguirse socialmente. De este modo, según Bourdieu, las constelaciones particulares del gusto, las preferencias de consumo y las prácticas de estilo de vida están asociadas con ocupaciones específicas y pertenencias de clase, mediante oposiciones estructuradas y estructurantes, que operan dentro de la sociedad en cada momento histórico concreto.

Estos conjuntos relativamente estables de principios clasificatorios y disposiciones grupales, se internalizan individualmente a través del habitus (Bourdieu. 1979 : 169 y ss.) de clase o de grupo, son socialmente reconocibles y operan para establecer las demarcaciones de estilos de vida entre los distintos segmentos sociales. Por ello, cada uno de estos segmentos socializa diferencialmente a sus neófitos en un estilo de vida adecuado a su estatus grupal. Esto trae consigo una inversión de todo el ciclo de vida en capital cultural y tiempo para mantener las actividades de consumo. Es importante resaltar que el habitus no sólo opera en el nivel del acceso al consumo de objetos externos, sino que una parte fundamental de él se inscribe en el "cuerpo". Así, según Bourdieu: "El cuerpo es la más irrecusable objetivación del gusto de clase, que manifiesta de diversas maneras. En primer lugar, en lo que tiene de más natural en apariencia, es decir, en las dimensiones (volumen, estatura y peso, etc.) y en las formas (redondas o cuadradas, rígidas y flexibles, rectas o curvas, etc.) de su conformación visible, en las que se expresa de mil maneras toda una relación con el cuerpo, esto es, toda una manera de tratar el cuerpo, de cuidarlo, de nutrirlo, de 
mantenerlo, que es reveladora de las disposiciones más profundas del habitus" (P. Bourdieu. 1979 : 188).

Siguiendo la teoría de Bourdieu, las clases están en pugna y los bienes son las armas de esta competición, pues los grupos sociales altos y medios utilizan el consumo como medio de apropiarse de signos de distinción, que operan como barreras de estatus respecto a las clases inferiores que, si quieren ascender en la escala social del prestigio, tienen que apropiarse de esos signos (objetos de consumo) de distinción. Pero cuando aquellos advierten que sus signos de distinción están siendo imitados, se ven abocados a eliminarlos por obsoletos, pasando a sustituirlos por otros nuevos y más selectivos (más caros y sofisticados). Así conforme el estilo de vida de la cúspide de la pirámide social se irradia hacia la base. Pero las clases altas deben consumir e innovar si es que quieren diferenciarse socialmente de las demás; mientras que las clases inferiores, deben consumir e imitar, si es que desean ascender hacia la cúspide. Resulta entonces que el suministro constante de bienes nuevos y distinguidos por parte de la oferta, produce un efecto de juego de persecución de roles de apropiación, por el cual todos los grupos sociales se ven impelidos a invertir en nuevos bienes, para mantener o conseguir la distinción y con ella la distancia social anhelada.

Los bienes de consumo, entonces, están implicados en definiciones y redefiniciones sin fin de una siempre cambiante estratificación social. Esta liza social entre los distintos criterios de gusto y distinción, hechos estilos de vida, puede entenderse mejor, según Bourdieu, estudiando el habitus de la "nueva pequeña burguesía" que, ávida de movilidad social ascendente, suele estar muy preocupada por extender y legitimar sus propias disposiciones particulares de consumo y de estilo de vida (Bourdieu. 1979 : 358 y ss). En este contexto la información y el conocimiento sobre el consumo llega a ser relevante, pues la estrategia de distinción social depende del conocimiento de los nuevos bienes, de su valor social y cultural, y de cómo usarlos 
apropiadamente, dentro de un adecuado estilo de vida. Por ello es muy importante el papel de los medios de comunicación (revistas de la cultura del consumo, periódicos, libros, programas de la televisión y la radio), los cuales resaltan la automejora, el autodesarrollo, la transformación personal y, en definitiva, cómo construir un estilo de vida diferencial y realizativo, alejándose del totum revolutum de los estilos de vida convencionales.

Por otro lado y, dadas las condiciones de un suministro creciente de bienes simbólicos destinada a atender a la enorme pluralidad estratificativa, crece progresivamente la demanda de los expertos en intermediación cultural, que tienen la capacidad de ofrecer informaciones, conocimientos y prácticas. Por eso es muy relevante el papel que Bourdieu concede a los nuevos intermediarios culturales, cuya trayectoria es creciente dentro del espacio social, con la función de proporcionar bienes y servicios simbólicos, mediando entre la oferta, la demanda y los medios de comunicación: "La nueva pequeña burguesía se realiza en las profesiones de presentación y representación -representantes de comercio y publicitarios, especialistas de relaciones públicas, de la moda y de la decoración, etc.- y en todas las instituciones dedicadas a la venta de bienes y de servicios simbólicos". P. Bourdieu. 1979 : 363). Estos nuevos intermediarios culturales son, en gran medida, responsables de la constitución social de un "nuevo narcisismo", a partir del cual los individuos buscan aumentar al máximo y experimentar el mayor rango de sensaciones y experiencias disponibles en el mercado. La búsqueda de la expresión y autoexpresión, la fascinación por la identidad, la presentación y la apariencia hacen del nuevo pequeño burgués un consumidor perfecto.

En resumen, el consumo, para Bourdieu, es un proceso social sometido a cambio. Cambio social impuesto, por un lado, por la lógica de las luchas de los grupos sociales en la producción, y que se organizan en torno a la disputa por los mejores estatus profesionales y sus capacidades adquisitivas; $y$, por otro, por la lógica de las 
luchas simbólicas en torno al consumo de símbolos de estatus, que enfrenta a los poseedores y a los pretendientes más pretenciosos y con mayor motivo de logro en diferenciarse y distinguirse de los demás.

\subsection{George Ritzer, o el consumo como el "encanto de un mundo desencantado".}

En línea con el análisis de Weber se encuentra la obra de George Ritzer, que continúa la investigación weberiana de los órdenes culturales y su impacto en las formas y estilos de vida cotidianos. Ritzer aborda el actual calado de la racionalización de la vida cotidiana a través del análisis del consumo moderno de comida y sus profundas implicaciones sociales en su obra "The McDonaldization thesis: explorations and extensions" (1998), cuya tesis sobre la McDonalización social, nos actualiza la teorización weberiana sobre la racionalización y el desencantamiento de las prácticas sociales sustantivas. Anfibológica perspectiva que este autor ve expresa en los nuevos espacios del consumo rápido de comida. Posteriormente, Ritzer, siguiendo la pista inaugurada por Baudrillard, ha analizado, en una reciente obra titulada "El encanto de un mundo desencantado" (1999), la evolución a lo largo del presente siglo de los escenarios del consumo, que él conceptualiza como "catedrales del consumo" ("el mundo Disney", los restaurantes de comida rápida, las supertiendas, las tiendas de descuento, los centros comerciales electrónicos, los cruceros, los casinos, los parques temáticos, etc.), aludiendo con ello a la naturaleza "encantadora", cuasireligiosa de los mismos, pues se han convertido en los santuarios de la nueva religión secular del consumo. Pasemos ahora a presentar a los autores de la perspectiva apologética, entusiastas, a su modo, de las formas de vida consumistas. 


\section{Perspectiva apologética: el consumo desde la perspectiva de los que prefieren "desayunar en Tiffany's"}

Las aproximaciones apologéticas, en términos generales, entienden el consumo como una profundización en la libertad y la expansión de la personalidad, por lo que sus investigaciones suelen estar orientadas hacia la conceptualización de las cuestiones relativas a las satisfacciones hedonistas, emocionales y estéticas derivadas de las experiencias de consumo, pero no en base a la existencia de alguna lógica de manipulación sociopsicológica, sino en términos de lo que para esta perspectiva va a ser el vector fundamental, esto es, la incesante y optimizadora metamorfosis de la personalidad y de sus correspondientes formas de vida. Esta perspectiva participa de una cierta ontología focalizada en torno a una personalidad (individual y colectiva) abierta, dinámica (en proceso de expansión permanente) y hedonista, por eso el consumo va a ser entendido como un medio imprescindible para cumplimentar dichas características. Luego, al situar el acento en el consumo como dispositivo hedonista, incluso orgiástico (propio de la ontología del gasto y de la antropología del potlatch), va a preocuparse por estudiar los placeres y goces derivados del consumo, así como de los sueños y deseos que llegan a ser reforzados por el imaginario cultural de consumo, los cuales generan nuevas intensidades y placeres, así como nuevas expectativas de identidad y/o diferencia. Perspectivas que, de forma coloquial, he decidido rotular como la de aquellos que prefieren comenzar el día "desayunando en Tiffany's".

En consecuencia y, frente a la tendencia dominante presente en los anteriores enfoques, de una comprensión de la sociología del consumo como el estudio de los mecanismos de competencia vertical entre las clases y los grupos sociales, esta perspectiva tiende a interpretar el consumo como expresión y goce de la agencia individual y grupal. Agencia que es entendida más en términos de movilidad social horizontal (como maximización de las relaciones sociales que el propio consumo 
posibilita: nuevas comunidades morales, nuevos enclaves o sectores de estilos de vida, etc.), que en términos de jerarquía vertical (como diferencia y distinción de clase, dentro de la pirámide estratificativa). Hay que hacer la siguiente salvedad sobre este tipo de aproximaciones, pues al gravitar sobre un consumo hedonista, incluso orgiástico, se adentran en el proceloso océano de la cuestión del "deseo", difícil de aceptar por la investigación sociológica al uso, por su presunto "esencialismo" en la teoría, y porque hace resbaladizos los habituales métodos estadísticos sobre hábitos de consumo, para reconocer, por el contrario, el valor de una fuente genética, altamente problemática para la sociología convencional, pero que sin embargo explica su desarrollo: la ontología orgiástica de la naturaleza humana, y su genealogía, como diría Nietzsche, típicamente dionisíaca que entronca con todas las fiestas y rituales colectivos destinados a la celebración de la deidad del exceso (Dionisos o Baco).

Sin embargo, este tipo de consumo hedonista y orgiástico ha existido siempre al margen de los condicionamientos históricos y socioculturales por un lado, y de los psicopatológicos, por otro. Por ello, a pesar de todo, ha tenido que ser reconocido por parte de la sociología más creativa, más fronteriza con las dos áreas de conocimiento que más la han estudiado, la filosófica y la antropológica. Pues, desde el hontanar de la sabiduría trágica, que Nietzsche actualizase en el "El nacimiento de la tragedia" (1872), todo acto de consumo posee un dualismo jánico: un costado tiene que ser gastado y derrochado, para que otro se nutra y alimente a su costa, pues no hay ganancia sin pérdida, ni adquisición sin gasto (este es el peaje impuesto intemporalmente por el viejo Dionisos). Pero esto no es sólo invención del filósofo de Sils-Maria, ni la impertinente actualización del mitologema pagano; la propia palabra "consumir" está cargada de connotaciones negativas en todas las lenguas occidentales, como sinónimo de agotamiento y destrucción, pues uno de los usos más tempranos del término consumo significa "destruir, usar, gastar, agotar". De ahí, que el Diccionario de la Real Academia Española mantenga el sentido consuntivo de la palabra unido al adquisitivo (consumir del latín consumere: destruir, extinguir, 
utilizar comestibles perecederos $\mathrm{u}$ otros géneros de vida efímera para satisfacer necesidades o gustos pasajeros, gastar energía o un producto energético, desazonar, apurar, afligir). Pero, como apunta Featherstone (1991 : 21), este tipo de consumo como gasto, exceso y derroche representa una cuestión paradójica dentro del predominante carácter racionalista, ascético y productivo de la sociedad capitalista (y también socialista, como ya denunciara J. Baudrillard. 1973 : 163) y tardocapitalista, con su énfasis en el autoconocimiento y en el selfcontrol (A. Giddens. 1991), en la cultura y en la ciencia (E. Lamo de Espinosa. 1996) y en la reflexividad (U. Beck, A. Giddens y S. Lash. 1994).

Aunque cabe precisar que, simultáneamente a que reinan mayoritariamente estos valores del conocimiento, el autocontrol, la reflexividad, como nuevas formas de revitalizar los más vetustos del esfuerzo, la disciplina, la ascesis y el consumo necesario y mesuroso, sin embargo, conviven, entre nosotros, otras nociones consumistas en una dirección contraria, que sitúan el acento en el consumo hedonista, el cuidado corporal, el background de experiencias sexuales, la exploración emocional para amplificar la potencia de la personalidad o el uso de diversas substancias como intensificadores existenciales. Consumos que cuestionan las nociones prevalentes convencionales, incentivando el consumo como exceso y el gusto por la transgresión. Especialmente entre grupos más jóvenes de la población (que no han vivido las restricciones impuestas por la socialización fordista-taylorista). Esto ocurre en el contexto de las sociedades occidentales, donde, tras el desfondamiento de las utopías revolucionarias y el declive del colectivismo alternativo, reverdece una fuerte tendencia hacia un individualismo (N. Elias. 1987; A. Renau. 1989) preocupado por el uso de los placeres y el cuidado de sí (M. Foucault. 1976. 1984.1984b) y el énfasis en los valores corporales (B.S. Turner. 1984; A. Giddens. 1991; C. Shilling. 1993), que se traduce en un crepúsculo de la moral ascética y productiva (D. Bell. 1976; G. Lipovetsky. 1994; F. Fukuyama. 1999) y su metamorfosis en una nueva ética orientada 
hacia el hedonismo y la autorrealización de un individuo inserto en los diferentes sectores de estilo de vida (G. Lipovetsky. 1986; A. Giddens. 1991. 1992).

Desde luego todo esto no es independiente a la lógica del mercado y su subsecuente oferta de productos de consumo, que ha orientado sus ventas, mediante el eje del marketing y de la publicidad, incentivando el diseño hedonista de la producción de bienes, así como las imágenes simbólicas que circundan los artículos, pensando en la exclusividad de cada uno de ellos, para así dar satisfacción diferenciada al singular deseo de los consumidores. Pero ahora conviene retornar a los antecedentes teóricos para explicar este tipo de consumo, pues, desde luego, su actualidad no es una cuestión de oportunidad. Para ello, he considerado pertinente rescatar el enfoque clásico de la evolución social de Herbert Spencer, a mi juicio, de fundamental importancia por su incidencia en la actual teoría antropológica de Mary Douglas y Baron Isherwood. Mientras que, por otro lado, presento la noción de "consumo improductivo" de George Bataille, cuya tradición actualizarán, cada uno a su modo, M. Maffesoli, C. Grignon y J.C. Passeron. Ambas teorizaciones, las de Spencer y Bataille, por tanto, van a tener una crucial importancia en el reconocimiento del costado positivo del consumo.

\subsection{Herbert Spencer, o la evolución hacia un consumo más diverso y plural.}

Desde la perspectiva organicista de Herbert Spencer (1877-1896) se considera la evolución como clave de la realidad. Así, su sociología surge como reflexión sobre la evolución general y sus manifestaciones societales a lo largo de la historia. La idea central de su pensamiento es que la evolución procede desde la uniformidad estructural a la complejidad, o como él decía, a la heterogeneidad. De este modo y, siguiendo en esto a la poco reconocida tradición de la ilustración inglesa (Harvey, Hobbes, Mandeville y Darwin), para Spencer la igualdad (homogeneidad) de los 
hombres es una verdad (orgánica, natural); mientras que la desigualdad (la diferencia, la heterogeneidad) constituye el acicate y el verdadero eje de la evolución cultural (tanto en el ciclo de vida individual como en los ciclos de las sociedades); y además es el factor de civilización cuya pérdida sumiría a la humanidad en la barbarie de los orígenes (la de la "vida solitaria, pobre, desagradable, brutal y corta", según Hobbes). Según Spencer, al tener lugar el aumento estructural y de tamaño de las sociedades humanas durante la evolución, la diferenciación de las partes que componen el sistema se incrementa. Pero al tiempo, crece la independencia de estas partes en una disimilitud creciente que va de lo simple a lo complejo y de lo homogéneo (indefinido e incoherente) a lo heterogéneo (definido y coherente). Además, Spencer establece una segunda tipología complementaria de la anterior: sociedad militar y sociedad industrial. En la primera, prevalece la función militar que estructura y ordena la sociedad en base a una cooperación vinculante y obligatoria. Mientras que en la sociedad industrial, aparece el reconocimiento de la autonomía y libertad de las personas, en base a una cooperación voluntaria, fruto del interés individual vinculado por la relación contractual.

Por ello, la teoría de la evolución social spenceriana reconoce e instituye la elección libre y autónoma por parte del individuo, haciendo plausible con ello el régimen de consumo individualista y hedonista. Y para confirmarlo tenemos su propio testimonio autobiográfico, que refleja la vida de un self-made-man, que se resiste a las instituciones y aborrece la burocracia, escribiendo antes de morir su densa autobiografía en cuatro tomos. ¿No es un ejemplo paradigmático de su doctrina de la evolución, presentarse como epítome individualista, dedicado a la tarea de "construirse a sí mismo", mientras fundamenta una doctrina de la evolución social que tiene por diana las sociedades complejas, heteróclitas, contractuales y hedonistas en las cuales hoy nos hallamos?. ¿No es igualmente cierto, siguiendo a Spencer, que una mayor evolución cultural es causa de una mayor extensión de los estilos de vida $\mathrm{y}$, por tanto, un mayor y más diversificado consumo, que se convierte de esta forma 
en un indicador básico de evolución social y de calidad de vida, en un marco social abierto a una cada vez mayor pluralidad de las diversas identidades culturales y de sus múltiples estilos de vida?

Contra la visión de una cultura de masas conformista y gris, en la cual la demanda de bienes de consumo se conforma con los propósitos estratégicamente diseñados por la oferta (con el apoyo del marketing y la publicidad), siguiendo el criterio de la evolución spenceriana, cabe entender que el significado y uso de los bienes de consumo es un asunto complejo y problemático que, en gran medida, depende de la agencia individual y de su capital simbólico (saber diferenciar, seleccionar y elegir los bienes de consumo) y social (saber escoger la pertenencia a los sectores de estilos de vida adecuados a su idiosincrasia). Por tanto, parece que el tiempo ha venido a dar la razón a H. Spencer. Así, en las sociedades occidentales, compuestas por individuos y por grupos de estilo de vida cada vez más heteróclitos y diferenciados, el consumo se convierte en un proceso determinante en la construcción de la personalidad individual y también de la colectiva (los sectores de estilos de vida, de la que nos habla A. Giddens. 1991.1992). En consecuencia, desde la visión spenceriana cabe interpretar, por tanto, la cultura del consumo como construida en gran parte a partir de la agencia de la demanda y, además, teniendo en cuenta un básico acoplamiento entre la oferta y la demanda. Sin este equilibrio entre deseo de la demanda y estrategia de la oferta es impensable el general consenso en torno al consumo. Es más, para Spencer, el consensuado modelo de la sociedad de consumo constituiría el actual indicador de evolución social, tras la hegemonía de los modelos militar e industrial.

Quizá la objeción principal a la perspectiva utilitarista en general, y a la spenceriana en particular, es que el deseo (de la demanda) esté dirigido y orientado por la razón utilitaria, pues desde el análisis freudiano el deseo es una dinámica inconsciente e ilimitada y, además, entendido en su dimensión más profunda, no es otra cosa que 
un desplazamiento (Freud) metonímico (Lacan) hacia las dianas puntuales e insatisfactorias que son los diferentes objetos, con cuyo consumo se trata de obturar, o mejor de "denegar" la estructural falta de satisfacción, ya que el "objeto primordial", ese que, de forma latente, opera en toda demanda, es siempre un objeto perdido. Sin embargo, esta formulación racionalista del deseo, así como su ubicación dentro del marco evolucionista, propia de la teorización spenceriana, ha sido retomada por la teoría económica mainstream (por eso la figura del "preferidor racional" es su paradigma) y también, aunque de forma incoada, está presente en las obras de Mary Douglas y Baron Isherwood que a continuación vamos a ver.

\subsection{Mary Douglas y Baron Isherwood, en defensa del consumidor.}

La antropología siempre ha tenido una preocupación especial con el consumo visto como un sistema de signos, en el que convergen prácticas y significados socioculturales compartidos. Una síntesis del legado antropológico para la sociología del consumo sería que las capacidades, sentidos y experiencias de los consumidores, no sólo son centrales para el confort y la calidad de vida de ellos mismos, sino también para la formación y el mantenimiento de los sistemas socioculturales. Dado que, el consumo, como la mayor parte de las prácticas sociales, pone en juego una serie de interacciones sociales no sólo restringidas al intercambio de bienes necesarios para la subsistencia, sino que también remiten a otro tipo de interacciones más sustantivas, que tienen que ver con cuestiones socioculturales más sofisticadas como la cumplimentación de rituales a través del consumo suntuario, la fiesta como "donación interesada" (potlatch), etc.,. Es difícil subestimar, en este sentido, la importancia de la teorización pionera de Marcel Mauss sobre la naturaleza del intercambio en las sociedades primitivas, pues en su "Essai sur le don" (1923-1924), presentó la primera sistematización del complejo hecho del intercambio, entre el que se encuentra el consumo de los objetos que poseen un "alma", una espiritualidad 
(mana), que representa una práctica fundante en el intercambio y en la interacción social.

En la antropología contemporánea esta línea de análisis ha sido retomada por los trabajos de Mary Douglas "Pureza y peligro" (1966) y "Símbolos naturales" (1970), en los que ha analizado la importancia de las metáforas del consumo en el análisis del riesgo y la incertidumbre para el orden y/o el desorden de la sociedad. Douglas trata de evitar una concepción naturalista, que identifica el consumo con el intercambio económico en sentido estricto: "Ante todo deberíamos cuestionar la asociación de la sociedad de consumo con la producción capitalista" (Douglas. 1996 : 119), porque, para esta autora, el consumo es sobre todo un medio de pensar metafóricamente las relaciones entre prácticas y significados sociales y culturales. En "The World of Goods" (1979), Mary Douglas, en colaboración con el economista Baron Isherwood, arguye que los bienes funcionan simbólicamente como un código o lenguaje y como medio de hacer inteligible la conducta social. Ambos intentan encontrar una definición antropológica del consumo, que pueda aplicarse tanto a nuestras sociedades como a las sociedades tribales, partiendo del legado evolutivo spenceriano: libre elección del consumidor, y la idea de que el consumo es una significativa práctica en la evolución social que, además, comienza cuando el intercambio económico acaba. En consecuencia, definen el consumo como: "un uso de posesiones materiales que está más allá del comercio y es libre dentro de la ley, por ello, tenemos un concepto que viaja muy bien, cumpliendo usos paralelos en todas aquellas tribus que no tienen comercio". (Douglas e Isherwood. 1979 : 37). Su propósito es superar la concepción naif del pensamiento económico sobre el consumo, para entender la significación de los bienes de consumo, menos por lo que ellos pueden "hacer" por el consumidor, y más por lo que ellos pueden "decir" del mismo. Los bienes, afirman, son "comunicadores" que hacen "visibles y estables las categoría de la cultura". 
En consecuencia, las prácticas de consumo constituyen un sustantivo flujo vital de la cultura, pues la gente con sus decisiones está encarnando no sólo la circulación de significados culturales asignados a los distintos bienes, sino que está llevando a cabo toda una ética de la existencia, que es la que verdaderamente funda y sostiene la estabilidad del orden social, proporcionándole una dirección evolutiva: "Las decisiones relativas al consumo son la fuente vital de la cultura del momento... Por ejemplo, las amas de casa hacen la compra y destinan cosas para el hogar, para el padre, para los hijos, para los invitados. Deciden qué poner de comer, qué partes de la casa mostrar, a quién invitar, que música se tiene que oír, qué tipo de bebida y de conversación son las adecuadas... Estas elecciones expresan y generan cultura en su sentido general.. Además, serán libres, si la cultura está viva y en evolución. En última instancia, son juicios morales sobre lo qué es un hombre, lo qué es una mujer, cómo un hombre debería tratar a sus padres mayores, etc.. Estas son elecciones de consumo que pueden bien implicar grandes costes, pero un vez realizadas, pueden también determinar la evolución de la cultura". (Douglas e Isherwood. 1979 : 37). Ahora bien, el matiz que agregan estos autores, es que esta consideración de que los bienes de consumo al ser inseparables de su significado social, éste tiene que ser entendido dentro de una matriz cultural, es decir, los artículos de consumo no están destinados a cumplimentar exclusivamente las estrategias hedonistas e individuales del estereotipo de consumidor habitualmente adoptado por el pensamiento económico y por la teoría del intercambio, ni tampoco a cumplimentar el mandato social por parte de la oferta; sino que su fin último es aportar una categorización estructurada de bienes correspondiente a un sistema similar de necesidades, asignaciones y divisiones sociales.

Los bienes de consumo, en consecuencia, siempre llevan implícitos significados de las distintas funciones (jerarquía, prestigio, pertenencia, adecuación o no a las reglas) y relaciones (de parentesco, de amistad, de poder, etc.,), y son una articulación entre los diferentes estratos sociales y la estructura social correspondiente: "Dentro del 
espacio y tiempo disponible el individuo usa el consumo para decir algo sobre sí mismo, su familia, su localidad, ya sea en la ciudad o en el campo, en vacaciones o en el hogar. La clase de afirmaciones que a través del consumo hace, son sobre el tipo de universo en el que vive, y si dichas afirmaciones validan o desafían el orden social... El consumo, por tanto, es un proceso activo por el cual todas las categorías sociales están siendo continuamente redefinidas" (Douglas e Isherwood. 1979 : 45). Por ello, para Douglas e Isherwood, la función esencial del consumo es menos la satisfacción de necesidades primarias, y más su capacidad estructural para dar sentido cohesivo y estable a las principales prácticas y funciones sociales. Por ello y, de acuerdo siempre con la teoría de la evolución spenceriana, para Douglas e Isherwood, lo importante del consumo es que, mientras los significados de una cultura son cambiantes (tanto en el tiempo como el lugar), sin embargo los "rituales del consumo" proveen un sistema de significados que proporcionan sentido y estabilidad a la vida social.

En consecuencia, los bienes de consumo son medios "rituales" que proporcionan inteligibilidad a la conducta (pueden ser vistos como un mapa cognitivo más o menos fiable de la realidad social) y, con ello, favorecen la cohesión y estabilidad de la comunidad. Pues: "El principal problema de la vida social es atribuir y fijar significados consensuados de tal forma que permanezcan estables, al menos, durante un cierto tiempo. Sin algunas formas convencionales de seleccionar y fijar significados acordados, la base mínima consensual de la sociedad se desvanece. Tanto en la sociedad tribal, como en la nuestra, los rituales sirven para contener el cambio de significados. Los rituales son convenciones que hacen visibles las definiciones públicas.... Los rituales más efectivos utilizan cosas materiales ... Los bienes, en esta perspectiva, son rituales adjuntos; el consumo es un proceso ritual cuya función primaria es crear sentido para el flujo incoado de eventos" (Douglas e Isherwood. $1979: 43)$. 
La principal diferencia entre el tipo de análisis cultural ofrecido por Douglas y Isherwood, y el considerado en las aproximaciones propias de la primera tendencia (los detractores del consumo), reside en que para éstas, la creación de estructuras de significado social se gestiona desde agencias externas tales como la oferta, la publicidad y los medios de comunicación. Sin embargo, para Douglas e Isherwood, la producción de significado social es vista como un resultado de un modo relativamente autónomo de acción sociocultural desarrollada por parte de los agentes. Este posicionamiento a favor de la agencia, conduce a Mary Douglas a teorizar ulteriormente "La rebelión del consumidor" (1996) y, lógicamente, lateralizarse a favor de "La defensa del salir de compras" (1997). Pues el consumidor, para Douglas, es alguien que, consumiendo, está encarnando funciones y roles que operan como significados de estatus, sobre todo en contextos como los actuales de alta competitividad social y fuerte anomia, frente a los cuales el auténtico comportamiento rebelde es el del consumidor (nómico, funcional, hedonista y de interacción social horizontal): "Un consumista es alguien que defiende el derecho de una persona a liberarse de la tiranía de su vecino sobre sus hábitos de consumo. Insisto en que debemos entender el consumo como una forma de rebelión" (Douglas. 1996:122). Por ello, en "La rebelión el consumidor", Douglas (1996:177 y ss.) defiende la racionalidad rebelde de las prácticas de consumo respecto de las atribuciones de inconsciencia e irreflexividad efectuadas por ciertos teóricos (la noción de habitus de Bourdieu, junto con la de "desorden social" por sobreconsumo, de Featherstone, comparten el punto de mira). Para Douglas, el "consumismo forma parte de un estilo de vida altamente competitivo... que necesita rodearse permanentemente de lujos con el propósito de exhibir recursos". (Douglas. 1996 : 133).

En suma, para Douglas, las preferencias en el gusto y las pautas de consumo de los individuos y grupos sociales son entendidas como comandadas por una dirección consciente y con propósito de proveerse de los bienes simbólicos necesarios para detentar y expresar su estatus, sobre todo en contextos muy competitivos y en 
sociedades anómicas en las que se han diluido los códigos y convenciones que rigen las reglas culturales. Los signos y símbolos de los objetos de consumo poseen, en esos difíciles momentos, una función de integración social, pues crean consenso sobre el sentido del mundo y este consenso perdura en el tiempo, proporcionando cohesión y estabilidad social.

\subsection{George Bataille y el consumo improductivo.}

Una parte integral de las aproximaciones críticas a la teoría económica dominante y al enorme poder de la oferta para modelar las pautas del consumo, tienden a considerar la conducta de consumo en su conformidad o desviación de la satisfacción de necesidades de uso y de su ratio respecto al precio, tendiendo a descartar como irracionales aquellas pautas de consumo que se desvían de la satisfacción de las necesidades cotidianas. De este modo, cabría argüir que permanecen sin ver, en el plano latente, la dimensión subyacente al consumo aparentemente racional. Como hemos visto anteriormente, tanto en el trabajo clásico de Veblen como en el más reciente de Bourdieu, el ocio y el consumo conspicuo aparecen como estrategias de distinción social destinadas a preservar el rango y el estatus de cada miembro de un grupo, manteniendo a raya las diferencias con los demás. Pero, tanto uno como otro autor no explican el consumo que, alejándose más allá de la satisfacción de necesidades cotidianas, se orienta hacia el gasto derrochador, bien guiado por el deseo de reconocimiento y/o autoafirmación social (potlatch) o por el puro placer de la intensificación orgiástica (éxtasis dionisiaco). Pero este tipo de "consumo conspicuo", de gasto derrochador no tiene que ser exclusivamente considerado como irracional; podría también implicar algún elemento de necesidad real, no patológica ni discriminante, aunque sí, desde luego, notablemente diferencial.

Para entender este tipo de consumo, es pertinente recurrir a Ángel de Lucas, pues en su ensayo sobre hermenéutica antropológica (1994 : 25-36) nos muestra que existen 
dos lógicas que rigen la interacción social sustantiva, una es: la "lógica del intercambio", que regula el toma y daca de las relaciones sociales en términos contables de debe y haber, de pérdidas y ganancias y, por tanto, está sometida al cálculo racional de las prestaciones y contraprestaciones; y otra es la "lógica del don" (expresa en el celebérrimo "Ensayo sobre el don" de M. Mauss. 1925), que rige las relaciones sociales del dar y tomar de forma expresiva/afectiva, asimétrica y diferencial. En este segundo tipo de lógica, en la del "don", hay que ubicar la teoría de George Bataille, y su noción de "consumo improductivo". Perspicaz analista de la cultura del consumo, George Bataille (1933 : 23-47) participa de la idea que, en el análisis de la economía general, la producción económica no debe asociarse a la escasez, sino al exceso. Para Bataille, en efecto, el objetivo de la producción es su dilapidación, y el problema clave consiste qué hacer con la "parte maldita", comprensiva del exceso de energía traducido en un exceso de productos y bienes, un proceso de crecimiento que si no se canaliza hacia el gasto y el derroche, deriva en un exceso de compulsividad y entropía. Pues, según Bataille, la vida humana no puede limitarse a los sistemas cerrados que le son asignados en condiciones razonables; ella sólo comienza, más allá del déficit de esos sistemas, en la "noción de exceso" que la constituye.

De este modo, para Bataille, la historia de la vida humana tiene un papel jánico, por un lado producir y acumular y, por otro, consumir y dilapidar. Pues, existe un "consumo productivo", útil y necesario para la conservación y reproducción de la vida y para la continuación de la actividad productiva, que es, por tanto, un medio cuyo fin es la subsistencia; y otro "consumo improductivo" (Bataille. 1933 : 32), que es fin en sí mismo y que convoca al lujo, el luto, las guerras, los cultos, los juegos, las artes, las fiestas, la actividad sexual perversa (desviada de la genital), y al que es inherente un principio de "pérdida" (gasto incondicional, no sometido al cálculo racional. Bataille. 1933 : 28 y ss.) que debe ser lo más notable posible, para que la actividad adquiera su más verdadero sentido. Pero, continúa Bataille, de estas dos 
nociones es la del "consumo improductivo" la que caracteriza a la naturaleza humana que desee sobre-vivir, ya que el destino del ser humano es el del cumplimiento inútil e infinito de su parte maldita, de su exceso económico/energético. El anthropos no es otra cosa que una ocasión oportuna para la dilapidación de sus mejores recursos, en eso radica su "principio de soberanía".

De lo que se deduce que la producción y la adquisición no son sino medios subordinados al consumo (lo prueba por medio de los estudios de M. Mauss sobre el intercambio primitivo). Pues, la riqueza como adquisición, en tanto que poder adquirido por ella, está dirigido hacia la pérdida/donación, en el sentido de que ese poder está caracterizado como "poder de pérdida/donación", pues es en ésta donde únicamente se alcanza el prestigio y el reconocimiento. Para Bataille, han sido las sociedades civilizadas las que han abandonado esta obligación funcional de la riqueza, la del derroche dilapidador, la del "consumo improductivo". Con la modernidad industrial, la burguesía se ha distinguido de la aristocracia, precisamente en que no ha conseguido gastar sino acumular más riqueza, institucionalizando la condición humillante del "gasto restringido". El odio al dispendio es la razón de ser y la justificación de la burguesía. Por ello, según Bataille, las sociedades capitalistas intentan encauzar la parte maldita en pleno crecimiento económico, producir el crecimiento sin fin. Pero, sin embargo, en ellas siempre están presentes restos de "consumo improductivo", pues en varios niveles hay pérdidas y goteos que persisten y, en los términos del argumento recién mencionado, en las sociedades tardocapitalistas se produce también un tipo de consumo que remite a los placeres de la orgía y el exceso a través de los siempre pre o postmodernos procesos suntuarios comprensivos de las fiestas, los carnavales y demás actos de consumo conspicuo (ya que transgreden y transcienden la lógica del intercambio y la racionalidad instrumental que la rige). 
En consecuencia, según Mike Featherstone (1991:22-23), los descriptores a contemplar, derivados de este tipo de consumo teorizado por Bataille, son los siguientes: (1) la persistencia dentro de la actual cultura de consumo de los elementos de la tradición carnavalesca preindustrial; (2) la transformación y desplazamiento de lo grotesco, lo festivo-popular, en las imágenes de los medios de comunicación, diseño y anuncios, videos de rock, el cine; (3) la persistencia y transformación de elementos de lo carnavalesco dentro de ciertos sitios de consumo: los lugares de vacaciones, los estadios de deportes, los parques temáticos, los grandes almacenes y los centros comerciales; (4) su desplazamiento e incorporación en el consumo conspicuo por las instituciones públicas y privadas en la forma de espectáculos o de cualquier otro complemento de la oferta turística. En contraste con las anteriores posiciones respecto al consumo (detractores y anfibológicos), que se inspiran en las nociones de racionalización, mercantilización, estratificación y modernización de la cultura, las cuales se distribuyen un kulturpessimismus crítico y/o nostálgico, existen dos líneas de trabajo, dentro de la escuela francesa de sociología, que se preocupan por retomar el legado batailleano, las cuales vamos a introducir sucintamente. Nos estamos refiriendo a la sociología de Michel Maffesoli y a la de Claude Grignon y Jean-Claude Passeron. Ambas preocupadas y ocupadas por atender a los distintos procesos dentro de la cultura popular de la transgresión, la protesta, los excesos carnavalescos y liminales (Maffesoli), los nuevos estilos de vida tribales (Grignon y Passeron) como nuevas formas de asentamientos sociales y de consumos conspicuos.

\subsection{Michel Maffesoli, o el consumo tribal, orgiástico y errático.}

Michel Maffesoli en sus diferentes obras retoma (1996. 1997) el "consumo conspicuo/dionisiaco" como característica fundamental de la tradición popular, presente en romerías, carnavales, ferias y fiestas. Ceremonias de consumo improductivo que suponen una evidente subversión simbólica de la cultura oficial 
burguesa, racional y utilitaria en sus actos de consumo; y que favorecen y estimulan las nuevas formas de vida "tribal" (Maffesoli. 1988) y sus tendencias hacia el "consumo improductivo", tanto en sus actividades orgiásticas (Maffesoli. 1996), como en la dionisíaca "pulsión de errancia" (Maffesoli. 1997). Esto es, los estilos de vida alternativos basados en la vida nómada, los accesos a la excitación, las emociones desenfrenadas y los placeres corporales grotescos directos y vulgares de comida que engorda, bebidas y alta promiscuidad sexual. Pues, para Maffesoli, lo verdaderamente irracional es el pensamiento del "preferidor racional", dado que supone una concepción del mundo como entramado de individuos que sopesan aisladamente probabilidades, calculan y deciden. Pues tal modelo de sujeto, parte de la idea de subjetividad acultural, sin anclajes institucionales, libre de ataduras (porque es lo que más interesa a una producción sometida a crónicas reconversiones, movilidades geográficas y polivalencias funcionales), pero incapaz de saber nada sobre el mundo en el que está instalado. Su drama es que no puede disponer de un conocimiento sedimentado en su identidad y en sus instituciones.

\subsection{Claude Grignon y Jean Claude-Passeron o las condiciones de posibilidad simbólicas del consumo popular.}

Claude Grignon y Jean-Claude-Passeron (1992), herederos inconfesos del estudio de "La parte maldita" de Bataille y del Baudrillard de "La economía política del signo", sitúan más su ambición en la teoría que en la praxis; su objetivo central es proveer de repertorio heurístico a las clases populares, informándoles de la fundamental importancia del "capital simbólico" para configurar los estilos de vida alternativos a los dominantes, y que constituyen los diferentes mundos sociales de la "cultura de la calle" que, en sus diferentes modalidades, siempre participan del "consumo dionisiaco", a partir del cual construir identidades, formas de vida y ritos de pertenencia. Por lo tanto, estos autores, se empeñan en deconstruir las referencias del modus vivendi de las clases dominantes (F. Alvárez-Uría. 1990), combatiendo el 
"consumo vicario" del que depende la constitución social del resto de las identidades; y, simultáneamente, desarrollan una teoría (más allá del miserabilismo y del populismo) y un repertorio metodológico, destinado a facilitar la conciencia y el reconocimiento de la autonomía simbólica de cada grupo social y su civilizada defensa respecto de los demás. El objetivo final es reparar, así, la injusticia heurística (simbólica) y praxiológica (de prácticas de consumo adecuadas a sus formas de vida) cometida con las formas de vida populares, por parte de la cultura dominante.

\subsection{Mike Featherstone, Pasi Falk y Colin Campbell: las nuevas teorizaciones sobre la cultura del consumo.}

Desde que Jameson (1984), Maffesoli (1988) y Baudrillard (1986), entre otros, describieran el actual estado de las sociedades (de la crisis de la modernidad) como postmodernista, esta descripción no ha tardado en cobrar auténtica relevancia para la sociología del consumo, porque sugiere que ha habido un crucial desplazamiento en los usos y funciones del consumo. Pues así como en la edad de oro de las sociedades occidentales (los primeros quince años de la segunda mitad del siglo, esto es, bajo el "modernismo" sociocultural), existía una relación directa y estable entre consumo y ubicación en la pirámide social, bajo el "postmodernismo", la relación fija y permanente entre consumo y pertenencia de clase se ha diluido profundamente, siendo sustituida por unas relaciones cada vez más diversas y plurales entre consumo y nuevas agrupaciones sociales, como la adscripción a los "sectores de estilo de vida" (Giddens : 1991. 1992), o a las "tribus" (Maffesoli. 1988), por poner dos ejemplos a mano. Como bien anticipó Baudrillard, los objetos de consumo descontextualizados de sus usos sociales de origen, reproducidos y serializados, han sido en gran medida liberados de sus amarras simbólicas y han comenzando a ser arrastrados por el mundo de los signos, disponibles para ser usados por distintos grupos en plurales y diversas formas. Por eso no resulta sorprendente que las clases con mayor poder adquisitivo se compren un futbolín para su casa, y las clases medias 
(cuando se lo permiten sus hipotecas) se compren un chalet en la floresta, o se hagan socios de una hípica o de un club de golf; así como, algunos de miembros de los sectores intelectuales, no tengan hoy tanto reparo en confesar su interés por actividades propias hasta ayer de la clase trabajadora: como el fútbol, las artes marciales o el ciclismo.

Por tanto, en lugar de la coherente colección de prácticas enclasadas y enclasantes que caracterizaba el consumo en la modernidad, actualmente asistimos a un deslizamiento más ecléctico en el consumo, que no se corresponde ni directa, ni establemente con los estatus de la esfera productiva. Cabe así inferir que, en la postmodernidad, el consumo de bienes y servicios no es un descriptor fiable del estatus social. Este marco general del cambio social descrito en términos del pasaje modernidad vs postmodernidad, es el que ha sido retomado por Mike Featherstone en "Consumer culture and postmodernism" (1991) que, dentro de la línea de trabajo de los "estudios culturales", ha abordado el consumo moderno, tematizándolo como el reino soberano para la construcción de la autoidentidad y sus correspondientes estilos de vida (muy en la línea de A. Giddens. 1991). Obra en la que presenta diversos materiales imprescindibles para entender nuestra actual sociedad de consumo: abordajes teóricos, tematización de los nuevos estilos de vida, etc.. Mike Featherstone en esta obra postula que el postmodernismo no debe ser comprendido como un cambio epocal (Bauman) o una nueva etapa del capitalismo (Jameson), sino más bien, como una llamada de atención hacia el cambio social acontecido y su impacto en las mediaciones entre economía y acción social, dentro de unas sociedades en las que predomina la información, la comunicación, la reflexividad; en definitiva, como afirma E. Lamo de Espinosa, unas sociedades en las que la cultura y el conocimiento son los vectores principales de la acción (1996). Consecuentemente, según Featherstone, el mundo postmoderno es aquél en el cual la cultura, ampliamente entendida, juega un rol principal, pues en lugar de consumir los bienes por sí mismos (esto es, por su necesidad), consumimos más los significados de dichos 
bienes (la significación sociopsicológica de los mismos). Este giro posmoderno supone, entre otras cosas, la sustitución de la concepción moderno-kantiana de la cultura del consumo (la "alta cultura" que propugna el consumo de objetos sublimes, elitistas y caros), por la concepción postmoderna y anti-kantiana del consumo que propugna el consumo inmediato, barato (todo a 100), sensual (no duda en remitir cualquier objeto al deseo), y populista en una dirección jovializadora, bien infantil y/o juvenil (Featherstone. 1991 : 71, 131).

En breve, algunas de las conclusiones más importantes de su estudio sobre las relaciones entre consumo y postmodernidad, son: 1/ la capacidad de fagotización que tienen las sociedades de consumo postmodernas, pues "dentro de la cultura del consumo a mujeres y hombres se les dice que no escojan, sino que incorporen ambas opciones" (Featherstone. 1991 : 27); 2/ el acentuamiento, anticipado por Benjamin, de la alegoría y la fascinación con que la publicidad impregna los artículos de consumo, que no duda en utilizar materiales oníricos y fantásticos para acentuar las ilusiones, sueños y alegorías que refuerzan las sensaciones estéticas, las vivencias románticas y, en definitiva, el refuerzo emocional para el consumo narcisista (de objetos exclusivos y excluyentes) (Featherstone. 1991 : 27); 3/ la cultura de consumo de hoy no reposa ni sobre el déficit en el control, ni sobre un control más rígido, sino sobre un lábil anclaje, que como plataforma giratoria permite manejar tanto el control (necesario para la producción y el consumo de las necesidades de subsistencia) como el descontrol (necesario para el consumo de bienes interactivos: espectáculos, fiestas, representaciones en vivo, viajes, encuentros en Internet, etc.), facilitando un transvase sencillo entre ambos polos, y todo ello para maximizar el consumo y aumentar la calidad de vida de los consumidores (Featherstone. 1991 : 20-21, 24).

Por otro lado y, en un primer momento, dentro del campo de la "sociología del cuerpo", la obra de Pasi Falk "The consuming body" (1994), conecta el análisis de la corporalidad con una teoría de la identidad contemporánea, para la cual es 
sustantivo realizarse a través del consumo. Según Falk, el sentido del yo en la sociedad contemporánea está profundamente conectado con la idea del consumo personal ilimitado (de comida, de signos y de bienes), el cual obedece a la nueva máxima ontológica: "yo consumo, por tanto soy", pues según este autor: "el concepto de sujeto ha sido sustituido (no eliminado) por el concepto de cuerpo, una transformación que dispersa (los cuerpos son múltiples), complejiza (los cuerpos son sistemas con leyes), e historiza (los cuerpos son productos finitos y contingentes) la subjetividad" (P. Falk. 1994 : 5). Según el matiz teórico de Falk es la imagen corporal la que juega el papel determinante en la interacción y evaluación de la personalidad en la arena pública. Son, por tanto, las diferentes formas corporales las que se convierten en diana de las industrias de servicios correspondientes (dietética, gimnástica, médica, etc. ) y sus dispositivos de publicidad asociados. Especialmente relevante es el capítulo quinto "Consuming desire", donde traza una genealogía discursiva del consumo moderno, siguiendo, lo que en el terreno del psicoanálisis se denomina: las dinámicas del deseo. Pasi Falk aborda también una "antropología del gusto" (capítulo cuatro), para la que es muy importante la cuestión del consumo de comida, dado que éste no sólo proporciona satisfacción de las necesidades alimentarias, sino que provee las distintas formas de solidaridad social, la comunitas, que se establece compartiendo la ingesta gastronómica.

Posteriormente, Falk, junto a Colin Campbell, ha editado "The shopping experience" (1997), obra comprensiva de varias colaboraciones sobre la "experiencia compradora", entendida como una actividad soberana por derecho propio. Publicación que se edita, según sus compiladores, con una clara tentativa de evitar tanto el reduccionismo característico de la economía y el marketing, como el tono moralizante de ciertos discursos sociológicos en su abordaje del "salir de compras". Ambos autores entienden la nueva significatividad atribuida al consumo, "por el rol central que ha alcanzado este fenómeno cultural en la sociedad postmoderna" contemporánea, donde es identificado como un reino de acción social, interacción y 
experiencia, que de forma creciente estructura las prácticas cotidianas de las gentes en las grandes urbes" (Falk y Campbell. 1997 : 1-2). Sin embargo, esta tesis no les conduce, como a Featherstone, a realizar una teorización generalista sobre la "postmodernidad", sino a prestar mayor atención a las actitudes y deseos de las gentes cuando compran, y qué significado dan a estas compras. Sin embargo, su aproximación rechaza la perspectiva del individualismo metodológico, porque consideran la experiencia compradora como un caso paradigmático que ilustra la pérdida de la centralidad de las actividades productivas, en beneficio de las prácticas y experiencias del consumo (Falk y Campbell. 1997 : 3). En su capítulo "The scopic regimes of shopping", Falk aborda la actualidad del placer "escópico" en el consumo, muy en línea con el análisis lacaniano de la "teoría del espejo", para concluir que el espacio del consumo es como una "ventana indiscreta", a partir de la cual se establecen una identidades constituidas a través de la fascinación de la imágenes destinadas a subyugar las miradas, en la apoteosis del placer visual (escópico), potenciado por la oferta y la publicidad.

Por otro lado, Colin Campbell, coeditor del libro, distanciándose de los análisis historicistas al uso, encuentra en los comportamientos de consumo la constante presencia de estéticas y mitologemas culturales que, para este autor, son las que verdaderamente crean los marcos simbólicos de las acciones y experiencias consumidoras. En concreto, Campbell ha estudiado las relaciones entre "romanticismo" y consumo en diferentes obras (1983. 1987), en las que sostiene la tesis de la importancia del "hedonismo mentalista" (y su necesidad de marcos simbólicos para la acción) en los comportamientos de consumo: "La actividad esencial del consumo no es la selección compra o uso actual de los productos, sino la búsqueda de placer imaginativo al cual se brinda la imagen del producto mismo, siendo en gran parte el consumo "real" una resultante de este "hedonismo mentalista"... La idea de que los consumidores contemporáneos tienen un deseo insaciable de adquirir objetos representa un malentendido serio del mecanismo que 
impele a la gente a desear objetos. Su motivación básica es el deseo de experimentar en la realidad los dramas placenteros que ya han disfrutado en la imaginación, y cada "nuevo" producto es visto como ofreciendo una posibilidad de realizar esta ambición (Colin Campbell. 1987:189-90). Su colaboración en "The shopping experience", "Shopping, pleauser and the sex war", aborda el consumo dentro del contexto general de las problemáticas de género.

\section{Triálogo, a modo de conclusión}

Tras describir lo que a mi juicio constituyen las tres grandes avenidas de la sociología del consumo, para concluir no encuentro mejor fórmula que la de proponer un diálogo con y entre cada una de ellas. Pues, esta entreveración conversacional quizá sea la mejor contribución que desde este estudio se pueda hacer a las futuras líneas de investigación sobre el tema. Por eso he rotulado este trabajo como "triálogo", que no quiere decir tres logos, sino conversación a través del logos entre las tres grandes maneras de cifrar la sociología del consumo. Tríalogo, pues, entre la primera perspectiva, la apocalíptica, que trabaja, desde el análisis dialéctico y materialista histórico, la vinculación del consumo con la estratificación social (con su asimétrica distribución de la riqueza y, por tanto, también de acceso al consumo), así como los negativos aspectos derivados de la misma: la manipulación por parte de la oferta y la intencionada alienación de la demanda. La segunda perspectiva, la anfibológica, que muestra las relaciones entre consumo y los estilos de vida convencionales y/o alternativos, así como el uso que de aquél se hace en los procesos de adscripción, desagregación y distinción social. Y, por último, la tercera visión, la apologética, que a través de la antropología, la sociología y los estudios culturales revela las relaciones del consumo con los procesos de identidad social, esclareciendo el grado de agencia individual, grupal y social, concurrente en las plurales y diversas prácticas del consumo. 
Todas estas perspectivas han hecho sus particulares contribuciones, por lo que en $\mathrm{mi}$ opinión ninguna puede ser rechazada in toto. Ahora bien, cada una de ellas tiene sus pros y sus contras, por eso interpelándolas y contrastándolas, esto es, haciéndolas conversar, es más probable que se encuentren líneas complementarias que compensen sus déficits particulares, a la par que incentiven sus mejores logros. Pues, si la sociología del consumo pretende ser un campo autónomo de conocimiento y praxis, algo más que un mero comentario alternativo a las limitaciones y fallos de las teorías económicas al uso, necesita de una robusta teorización que incorpore un verdadero triálogo entre las tres grandes perspectivas que hemos venido presentando de forma esquemática. Aunque esta propuesta de triálogo requiere un mayor desarrollo en ulteriores investigaciones, avanzaré algunas de las líneas de conversación que cabe realizar entre las tres grandes perspectivas.

Respecto a las teorías incluidas en la primera perspectiva, la "perspectiva apocalíptica", en su favor cabe decir que tienen razón cuando afirman que extender el certificado de defunción de la clase social (proclamado incluso por autores que he incluido en esta perspectiva; como Baudrillard) quizá sea algo precipitado, como también lo son sus efectos sobre el consumo, pues aún hoy son ciertas y significativas las relaciones entre clase social y conducta de consumo. También es muy importante el énfasis de esta perspectiva sobre el consumo destinado a cubrir las necesidades de supervivencia en amplios sectores de población, no ubicables dentro del marco ortodoxo de las clases sociales. En este sentido, la genérica llamada de atención de los autores de esta perspectiva es correcta, pues como ha puesto de relieve recientemente Bauman, el descuido de las preocupaciones relativas a la supervivencia es prematura, pues aún existen problemas severos en importantes segmentos de la población del tercer y cuarto mundo (enfermos, pobres y marginados). No obstante cabe resaltar que no hay que cerrar el angular de la investigación sobre las necesidades básicas, pues otros propósitos no tan primarios, pero también 
concurrentes en el consumo (reflexivos, expresivos, afectivos y psicosociales) han tenido y tienen indudable relevancia.

A mi juicio, esta perspectiva tiene el inconveniente de la excesiva politización de sus argumentos, ya que al centrar sus líneas de investigación sobre la problemática de la crítica al poder político y a sus ramificaciones productivas (la oferta), sitúa el acento sobre el estudio de las relaciones entre producción, clases sociales y consumo, y las condiciones y contradicciones que esas relaciones tienen en la estructura social a lo largo de la historia, las cuales proporcionan la base para los potenciales conflictos, rupturas y cambios (nacionalismo, terrorismo, consumismo), descuidando, por tanto, el estudio de la capacidad de agencia de la demanda y, con ello, los aspectos reflexivos, expresivos/afectivos, identitarios antes mencionados (si exceptuamos la defensa de De Certeau de las estrategias y tácticas de los consumidores, aunque también en términos de poder).

En consecuencia, la perspectiva apocalíptica, al no prestar atención a los factores sociopsicológicos del consumo, tampoco profundiza en sus pioneras tesis sobre la alienación (Marx), la cual es desarrollada con mayor calado por los autores de la segunda perspectiva, sobre todo por Simmel, Weber y Benjamin, cuyos análisis de la alienación, en mi opinión, son aún mucho más perspicaces que el de Marx, circunscrito estrictamente al ámbito de la producción. Respecto a la premisa de que el estatus de clase se evidencia a través del consumo ostentoso de bienes (Veblen, aunque también habría que incluir aquí a Bourdieu), por parte de las clases o grupos sociales de la denominada por Galbraith "sociedad opulenta", cabe hacer la salvedad de que quizá pasa por alto las nuevas estrategias de opacidad y ocultamiento por parte de las nuevas élites, por ejemplo, la de los bo-bos que, según V. Verdú, son un nuevo segmento social emergente en las sociedades occidentales. 
Respecto a la segunda gran avenida, la de la "perspectiva anfibológica", varios son los planos de rentabilidad que ofrece. Primero $y$, dentro de la dimensión metodológica, la relevancia de esta perspectiva consiste en la conceptualización de los antecedentes socioculturales de los diversos tipos de consumo, que culmina en una interpretación "simbólica" y "estética" del consumo, que al ser consideradas como bases sociales del gusto, inaugura, con los trabajos de Simmel, Weber y Benjamin, una nueva estratificación que reposa más sobre los criterios de elección y distinción relativos al consumo, que sobre la capacidad adquisitiva y la conciencia ideológica, propios de la esfera productiva. Este criterio estratificativo, actualizado y reelaborado, es la fuente del programa de investigación de Pierre Bourdieu.

A este estudio focalizado sobre las dimensiones simbólicas y estéticas, se le añade una segunda rentabilidad que consiste en esclarecer las razones prácticas que mueven a los individuos y a los grupos hacia la interacción social, a través de sus comportamientos relativos al consumo. Pues los autores de la perspectiva anfibológica tienden a desarrollar una "ética" de la interacción social, que dará a luz, en sus diferentes postulaciones, a una teoría de la acción estilizadora o del "estilo de vida", esgrimida como estrategia alternativa a las consecuencias indeseadas de los modos de vida convencionales, y que incentiva el aporte estilizador en un plano más psicosocial en Simmel, Weber y Benjamin; mientras que, en la aproximación de Bourdieu, es más sociológica, en su propuesta de una ética política, cuyo cometido es reafirmar la importancia de las diferencias y distinciones de las bases sociales del gusto.

En el plano metodológico, esta alternativa ética y estética del "estilo de vida" facilita pistas para la localización de los nuevos flâneurs contemporáneos y, con ellos, los emergentes sectores de estilo de vida, comandados por personas y grupos que han ido construyendo una gran reserva de capital cultural, para así encarar los nuevos retos y desafíos de la postmodernidad o tardo-modernidad. Una tercera rentabilidad 
de esta perspectiva la constituye el antes mencionado mayor calado de su crítica a la alienación relativa a los comportamientos de consumo (aunque podíamos incluir a Baudrillard y Jameson, cuyas obras están en sintonía con esta línea crítica). Primero, porque el consumo impone un sistema universal de signos que, por sí mismo, no constituye un lenguaje y, además, queda lejos de ser una comunicación significativa, dado que el imperativo (ahora universalista y globalizador) del consumo se impone al precio del empobrecimiento ontológico de unos individuos, exclusivamente identificados y evaluados solamente en términos de los objetos que poseen; $\mathrm{y}$, en segundo lugar, porque para los autores de esta perspectiva, las prácticas de consumo por sí mismas, sin una vectorialización que les proporcione sentido y valor para la acción significativa, deja disponibles a sus participantes a la dominación (entre otras cosas, porque no dominan el código o los lenguajes a través de los cuales se modelan sus comportamientos y establecen sus identidades), o a la anomia, al no contar con recursos de sentido que proporcionen orientación para sus vidas y sus correspondientes acontecimientos marcadores (nacimientos, emparejamientos, enfermedades y muerte).

La crítica que les realizarían, tanto los "detractores" como los "apologistas", podría resumirse en el argumento de que las exploraciones existentes en el mapa social del gusto no son una base suficiente para explicar las relaciones entre producción, consumo y estructura social. Entre las razones esgrimidas estarían: que gran parte de la conducta de consumo está determinada socialmente; y que las descripciones de los sistemas de diferencias (estilo de vida, calidad de vida, índices de confort, etc.,...) que se supone han superado las clases, son todavía imprecisos y carecen de líneas de investigación empírica sofisticada.

Todas las teorías incluidas en "perspectiva apologista", de una forma o de otra, conceden una significativa importancia a la agencia de los consumidores. Esta relevancia de la agencia consumidora no es sólo una cuestión ontológica, sino que 
ésta hace de base para su apuesta mayor, consistente en proponer una teoría sobre la constitución de la identidad, que tiene un doble plano, el de la autoconstitución y el de la heteroconstitución del yo. De ahí, que sus autores tiendan a adoptar una doble versión sobre las funciones del consumo en la constitución de la identidad, enfatizando unos lo que puede denominarse la prioritaria función del consumo en la "autoconstitución del yo" (perspectiva de la escuela inglesa. Spencer, Douglas e Isherwood, Featherstone, Falk, Campbell, etc), mientras otros atribuyen al consumo un fundamental cometido en la "heteroconstitución del yo" (perspectiva de la escuela francesa: Bataille, Maffesoli, Grignon y Passeron).

Las teorías que participan de la visión de la "autoconstitución yo", otorgan una poderosa agencia a los individuos, pues tienden a ver las elecciones en el campo del consumo como una estrategia instrumental y sin constricciones para la construcción de la identidad personal, otorgando quizá un excesivo peso a una noción del consumo como acción realizativa por excelencia del individuo. También sobreenfatizan el rol de los productos culturales (particularmente los resultados de los medida y los iconos de la moda) a expensas de la variedad de prácticas que crean y sostienen las relaciones sociales de parentesco, amistad y asociación. Pero de lo que se ocupan menos es del problema del ¿por qué grupos o clases diferentes consumen bienes diferentes que, a su vez, les proporcionan su propio sentido o distinción estratificativa o clasista del mundo?. Pregunta a la que intentan responder las teorías de las perspectivas anteriores $\mathrm{y}$, en especial, la de P. Bourdieu. Por otro lado, los autores proclives a ver en el consumo una práctica más dentro de la "heteroconstitución del yo" prestan mayor atención a cómo las identidades son logradas a través de la afiliación a los grupos juveniles, tribales, nacionales, étnicos, ocupacionales y/o de parentesco, y su enfoque es mas sociopsicológico. La idea básica es que consumir los mismos productos, así como compartir espacios y tiempos de ocio (en especial, viajes, fiestas, espectáculos y/o deportes "en vivo", experiencias sexuales, etc.), son las más robustas fuentes de satisfacción y, además, estas 
actividades realizadas en grupo incrementan el sentido de pertenencia y, con él, se constituye y afianza la identidad social, y sus sentimientos asociados de obligación vinculante, camaradería y comunión.

Una rentabilidad sustantiva de esta tercera perspectiva consiste en que algunos de sus autores han sido los únicos que han reconocido que la actual fase de investigación en la sociología del consumo está muy influenciada por el giro cultural dado en la teoría social, en concreto el debate modernidad vs postmodernidad. Aunque el estudio pionero fue el trabajo de F. Jameson (1984), sin embargo ha sido la obra de M. Featherstone (1991), la que ha puesto sobre el tapete que este debate ha generado dos efectos particularmente merecedores de ser reseñados. Primero, que al hegemónico modelo del "preferidor racional" derivado de la economía, han venido a añadírsele otros modelos como son: el del consumidor como "comunicador", el "buscador de identidad", el "rebelde"; y que esta eclosión de modelos consumistas han hecho emerger plurales y diversos "estilos de vida". Segundo, hay una apreciación de la complejidad del consumo, que ha suscitado nuevas cuestiones sobre sus funciones y propósitos. El consumo comprende un conjunto de prácticas que permiten a las personas expresar su autoidentidad, marcar su acomodación a ciertos enclaves/sectores de estilos de vida, acumular recursos, mostrar distinción social o hacerla opaca, asegurar la participación en actividades sociales y políticas o evitarlas, según hemos ido viendo a lo largo de este trabajo, en la dialéctica entre unas perspectivas y otras.

Para terminar, y como forma de distanciamiento de la semántica negativa implícita en el consumo como "ontología del tener", quisiera introducir como referencia hermenéutica compensatoria el ontologismo crítico de Martín Heidegger (1929), que en síntesis viene a proponer que el verdadero "ser" lo es en el "tiempo". Entrecruzamiento de lo ontológico y lo temporal que quizá ayude a redimensionar y releer de una manera diferente las tres grandes perspectivas, las cuales, en mi 
opinión, se caracterizan por una prevalencia de la temporalidad "futurista" en la primera, "retroprogresiva" en la segunda, y "presentista" en la tercera. Por ejemplo, y comenzando con el tiempo del consumo afín a esta última perspectiva, la de los "apologistas", del que cabe afirmar que es mayoritariamente el del "tiempo presente"; mientras que, por otro lado, sus teorizaciones participan de un tratamiento "antidiscursivo" de la cultura del consumo, para enfatizar y describir sus actuales aspectos icónicos, espectaculares y artísticos. La disciplina y dificultad de la cultura discursiva es sustituida por la inmediatez de la cultura visual, tribal, espectacular y sensual, una evolución definida por Maffesoli como el pasaje desde la responsabilidad histórica del "proletariado" o de la "burguesía", que "pudieron ser sujetos históricos que tenían una tarea que realizar" (Maffesoli 1988: 36) a la suspensión de la responsabilidad respecto al futuro de los nuevos agrupamientos humanos, las puntuales "tribus" de consumidores, que no tienen "un objetivo preciso", pues no constituyen ningún "sujeto de una historia en marcha" (Maffesoli $1988: 29)$.

La primera perspectiva, la de los "apocalípticos", como ancla sus investigaciones sobre la premisa principal de la critica al pasado y al presente en aras a un futurible mejor, hace del futuro, entendido como horizonte de progreso, su temporalidad sustantiva, desarrollando una tarea evaluativa del pasado y del presente en términos de obstáculos o resistencias a vencer, para la realización "progresiva" del futuro (reconciliado), objetivo último de sus metas. Altamente crítica con los descriptores icónicos, visuales y espectaculares del presentismo consumista, apuesta por su superación a través de una cultura discursiva que fundamente una vía emancipativa claramente sociopolítica (autonomía de la identidad y de sus formas de vida de los comportamientos de consumo impuestos desde la oferta). La segunda perspectiva, la de los "anfibológicos", sin embargo escoge un camino "retroprogresivo", es decir, consciente de que el crecimiento genuino es siempre el resultado de un proceso de ida y vuelta, establece unos criterios alternativos a la inmediatez del presente 
consumista y al futuro progresista, a partir de mirar hacia atrás. (recuérdese la figura del "Angelus Novus" benjaminiano), para así poder reactualizar los referentes cultos, ciertamente "monumentales", que desde el pasado puedan servir para configurar los usos y prácticas del consumo más apropiadas a los estilos de vida postconvencionales. Por tanto, es una perspectiva que también es discursiva y utiliza la estética como vía emancipativa.

\section{Bibliografía}

ALTHUSSER, L. y BALIBAR, E. (1967). Para leer el capital. Siglo XXI. 1969.

ALVAREZ URIA, F. (1990). Sociología crítica de la cultura popular: Más allá del miserabilismo y el populismo (Entrevista con C. Grignon) en Revista Archipiélago, n ${ }^{\circ} 5$. Barcelona. Pág. 131-139.

BATAILLE, G. (1933). La parte maldita. Edhasa. Barcelona. 1974.

BATAILLE, G. (1957). El erotismo. Tusquets. Barcelona. 1985.

BAUDRILLARD, J. (1968). El sistema de los objetos. Siglo. XXI. México. 1969.

BAUDRILLARD, J. (1970). La société de consommation: ses mythes, ses structures. Éditions Denoël. París.

BAUDRILLARD, J. (1972). Crítica de la economía política del signo. Siglo XXI. México. 1989.

BAUDRILLARD, J. (1973). El espejo de la producción. Gedisa. Barcelona. 1980.

BAUDRILLARD, J. (1978a). A la sombra de las mayorías silenciosas. Kairós. Barcelona.

BAUDRILLARD, J. (1978b). Cultura y simulacro. Kairós. Barcelona. 1998.

BAUDRILLARD, J. (1986). América. Anagrama. Barcelona. 1987.

BAUMAN, Z. (1997). Postmodernity and its discontens. Polity Press. Cambridge. UK.

BAUMAN, Z. (1998). "De la ética del trabajo a la estética del consumo". En BAUMAN, Z. (1998). Trabajo, consumismo y nuevos pobres. Gedisa. Barcelona. 2000.

BECK, U., GIDDENS, A. Y LASH, S. (1994). Modernización reflexiva. Política, tradición y estética en el orden social moderno. Alianza. Madrid. 1997. 
BELL, D. (1976). Las contradicciones culturales del capitalismo. Alianza. Madrid. 1982.

BELLAH, R., MADSEN, R., SULLIVAN, W.N., SWIDLER, A. \& TRIPTON, S.M. (1985). Hábitos del corazón. Alianza Universidad. Madrid. 1989.

BOURDIEU, P. (1979). La distinción: Criterios y bases sociales del gusto. Taurus. Madrid. 1998.

BOURDIEU, P. (1986). "Notas provisionales sobre la percepción social del cuerpo". En ALVAREZ-URIA, F. y VARELA, J. (1986). Materiales de sociología crítica. La Piqueta. Madrid.

BOURDIEU, P. (1998). La dominación masculina. Anagrama. Barcelona. 2000.

BUCK-MORSS, S (1989). Dialéctica de la mirada. Walter Benjamin y el proyecto de los Pasajes. La balsa de la Medusa. Visor. Madrid. 1995.

BUGRA A. and IRZIK, G. (1999). "Human needs, consumption, and social policy" en Revista Economics and Philosophy, no 15 (1999). Cambridge University Press. Pág. 187208.

CAMPBELL, C. (1983). "Romanticism and the Consumer Ethic: intimations of a Weber-style thesis". Sociological Analysis. Vol. 44. 4.

CAMPBELL, C. (1987). The Romantic Ethic and the Spirit of Modern Consumerism. Basil Blackwell. Oxford.

CAMPBELL, C. (1997). "Shopping, pleauser and the sex war". En -FALK, P. y CAMPBELL, C. (1997). The shopping experience. Sage. London.

CERTEAU, M. De (1984). "The practice of everyday life. University of California Press". Berkely. En -LEE, M. J. (ed) (2000). The consumer society reader. Blackwell Publishers Inc. Oxford. UK.

CORRIGAN, P. (1997). The sociology of consumption. Sage. London.

CRESPO, E. y SOLDEVILLA, C (2000) (ed). La constitución social de la subjetividad. Libros La Catarata. Madrid.

DIGGINS, J. P. (1978). El bardo del salvajismo. Thorstein Veblen y la teoría social moderna. FCE. México. 1983. 
DOUGLAS, M. (1966). Pureza y peligro. Un análisis de los conceptos de contaminación y tabú. Siglo XXI. Madrid. 1991.

DOUGLAS, M. (1970). Símbolos naturales. Alianza. Madrid. 1988.

DOUGLAS, M. and ISHERWOOD, B. (1979). The world of godds. Towards an anthropology of consumption. Routledge. London. 1996.

DOUGLAS, M. (1996). Estilos de pensar. Gedisa. Barcelona. 1998.

DOUGLAS, M. (1997). "In defence of shopping". En FALK, P. and CAMPBELL, C. (1997). The shopping experience. Sage. London.

EDGELL, S., HETHERINGTON, K. and WARDE, A. (1996). Consumption Matters. Blackwell Publishers. Oxford.

ELIAS, N. (1987). La sociedad de los individuos. Península. Barcelona. 1990.

FALK, P. (1994). The consuming body. Sage. London.

FALK, P. and CAMPBELL, C. (1997). The shopping experience. Sage. London.

FALK, P (1997). "The scopic regimes of shopping". En -FALK, P. and CAMPBELL, C. (1997). The shopping experience. Sage. London.

FEATHERSTONE, M. (1991). Consumer culture and postmodernism. Sage. London.

FEATHERSTONE, M. \& BURROWS, R. (1995a). Cyberspace, Cyberbodies, Cyberpunk. Cultures of technological embodiment. Sage Publications. London.

FEATHERSTONE, M. (1995b). Undoing culture. Globalization, posmodernism and identity. Sage Publications. London.

FOUCAULT, M. (1976). Historia de la sexualidad (l). La voluntad de saber. Siglo XXI. Méjico. 1978.

FOUCAULT, M. (1984a). Historia de la sexualidad (2). El uso de los placeres. Siglo XXI. Madrid. 1987.

FOUCAULT, M. (1984b). Historia de la sexualidad (3). La inquietud de sí. Siglo XXI. Madrid. 1987.

FUKUYAMA, F. (1999). La gran ruptura. Ediciones B. Sabadell. 2000.

GALBRAITH, J. K. (1958). La sociedad opulenta. Ariel. Barcelona. 1969.

GALBRAITH, J. K. (1992). La cultura de la satisfacción. Ariel. Barcelona. 
GARATE, I (1998). "Nostalgia es nombre de tango o la proximidad no consiste en semejanza". Clínica y análisis Grupal. Vol. 20 (3). Nº 79.

GIDDENS, A. (1990). Consecuencias de la Modernidad. Alianza. Madrid. 1993.

GIDDENS, A. (1991). Modernidad e identidad del yo. "El yo y la sociedad en la época contemporánea". Península. Barcelona.1995.

GIDDENS, A. (1992). La Transformación de la intimidad. Sexualidad, amor y erotismo en las sociedades modernas. Cátedra. Madrid. 1995.

GIL CALVO, E. (1998). Escritos entre líneas 1987-1998. Las tres Sorores. Zaragoza.

GONZALEZ GARCIA, J.Mª (1992). Las huellas de Fausto. La herencia de Goethe en la sociología de Max Weber. Tecnos. Madrid.

GONZALEZ GARCIA, J.Ma. (1994). "Cap. 11: Georg Simmel y Max Weber". En LAMO de ESPINOSA, GONZALEZ GARCIA, J.Mª y TORRES ALBERO, C. (1994). La sociología del conocimiento y de la ciencia. Alianza. Madrid.

GRIGNON, C. y PASSERON, J.C. (1992). Lo culto y lo popular: Miserabilismo y Populismo en Sociología y Literatura. La Piqueta. Madrid.

HEIDEGGER, M. (1929). El ser y el Tiempo. F.C.E. México. 1951.

HENNIS, W. (1983). "El problema central de Max Weber" en Revista de Estudios Políticos, $\mathrm{n}^{\circ}$ 93. Madrid.

HENNIS, W. (1987). "El tema de Max Weber: La personalidad y los ordenamientos vitales". En IGLESIAS, C. (1987). Historia y Pensamiento: Homenaje a Luis Diez del Corral. Eudema. Madrid.

HENNIS, W. (1988). Max Weber: Essays in Reconstruction. Allen \& Unwin. London. HORKHEIMER, M. y ADORNO, T.W. (1944). Dialéctica de la Ilustración. Trota. Madrid. 1994.

JAMESON, F. (1984a). El posmodernismo o la lógica cultural del capitalismo avanzado. Paidós. Barcelona. 1991.

JAMESON, F. (1984b). "Teorías de lo posmoderno". En JAMESON, F. (1998). El giro cultural. Escritos seleccionados sobre el posmodernismo: 1983-1998. Ediciones Manantial. Buenos Aires. 
JAMESON, F. (1988). "El posmodernismo y la sociedad de consumo". En JAMESON, F. (1998). El giro cultural. Escritos seleccionados sobre el posmodernismo: 1983-1998. Ediciones Manantial. Buenos Aires.

JAMESON, F. (1989). "Marxismo y posmodernismo". En JAMESON, F. (1998). El giro cultural. Escritos seleccionados sobre el posmodernismo: 1983-1998. Ediciones Manantial. Buenos Aires.

JAMESON, F. (1998). El giro cultural. Escritos seleccionados sobre el posmodernismo: 19831998. Ediciones Manantial. Buenos Aires.

KATONA, G. (1968). La sociedad de consumo de masas. Rialp. Madrid.

KELLNER, D. (ed) (1994). Baudrillard. A critical reader. Blackwell. Cambridge. Massachusetts. USA.

KEYNES, J.M. (1936). The general theory of employment, interest, and money. Harcourt, Brace \& World. New York.

LACAN, J. (1966). Escritos. I y II. Siglo XXI. México. 1984.

LAMO DE ESPINOSA, E. (1996). Sociedades de cultura, sociedades de ciencia. Ensayos sobre la condición moderna. Ediciones Nobel. Oviedo.

LEE, M. J. (1993). Consumer culture reborn. London. Routledge.

LEE, M. J. (ed) (2000). The consumer society reader. Blackwell Publishers Inc. Oxford. UK.

LIPOVETSKY, G. (1986). La era del vacío: Ensayos sobre el individualismo contemporáneo. Anagrama. Barcelona. 1989.

LIPOVETSKY, G. (1990). El imperio de lo efimero: La moda y su destino en las sociedades modernas. Anagrama. Barcelona.

LIPOVETSKY, G. (1994). El crepúsculo del deber. Anagrama. Barcelona.

LUCAS, A. de (1994). "Sociedad de consumo o sociedad de mercado: el caso de las comunidades kula" en Revista Política y Sociedad, nº 16. Madrid.

LUKACS, G. (1922). Historia y conciencia de clase. Grijalbo. Barcelona. 1969.

MAFFESOLI, M. (1988). El tiempo de las tribus. Icaria. Barcelona. 1990.

MAFFESOLI, M. (1996). De la orgía. Una aproximación sociológica. Ariel. Barcelona. 
MAFFESOLI, M. (1997). "La pulsion d’errance" en Revista Sociétés, no 56. Pág.5-13.

MANDEL, E. (1975). Late capitalism. New Left. London.

MARCUSE, H. (1954). El hombre unidimensional. Orbis. Barcelona. 1985.

MARINAS, J.M.(1994). "La fábula del bazar: Etica y cultura del consumo" en Revista Occidente, $\mathrm{n}^{\circ}$ 162. Noviembre 1994.

MARINAS, J.M. (1998). "Tendencias y emergentes de la cultura del consumo" en Revista Documentación Social, no 111. Abril-junio. Pág. 141-153.

MARINAS, J.M. (1999). "El bazar efímero: imágenes del consumo en Ramón Gómez de la Serna" en Revista La Balsa de la Medusa, n 50. Pág. 85-140.

MARINAS, J.M. (2000a). "Simmel y la cultura del consumo" en Revista REIS, nº 89. Enero-Marzo. Pág. 183-218.

MARINAS, J.M. (2000b). "La construcción discursiva de la identidad". En CRESPO, E. y SODEVILLA, C. (Editores). La constitución social de la subjetividad. Ediciones La Catarata. Madrid.

MARX, K. (1857-8). Líneas fundamentales de la crítica de la economía política. (Grundrisse).OME. Vol. 21. Grijalbo. Barcelona. 1977.

MARX, K. (1867a). El Capital. Libro I. Vol. 1. Siglo XXI. Madrid. 1978.

MARX, K. (1867b). El Capital. Libro I. Capítulo VI (inédito). "Resultados del proceso de producción inmediato". Colección Hilo Rojo. Ediciones Curso. Barcelona. 1997.

MAUSS, M. (1923-1924). "Ensayo sobre los dones. Motivo y forma del cambio en las sociedades primitivas". En MAUSS, M. (1991). Sociología y Antropología. Tecnos. Madrid.

MILLER, D. (ed) (1995). Acknowledging consumption: a review of new studies. Routledge. London.

MINSKY, R. (1998). Psychoanalysis and culture. Contemporary states of mind. Polity Press. Cambridge. UK.

NIETZSCHE, F. (1872). El nacimiento de la tragedia. Alianza. Madrid. 1991.

PENZ, G. P. (1986). Consumer sovereignty and human interests. Cambridge University Press. Cambridge. 
RENAU, A. (1989). La era del individuo. Destino. Barcelona. 1993.

RITZER, G. (1998). The MacDonaldization thesis: esplorations and extensions. Sage. London.

RITZER, G. (1999). El encanto de un mundo desencantado. Revolución en los medios de consumo. Ariel. Barcelona. 2000.

RODRIGUEZ IBAÑEZ, J.E. (2000). ¿Un nuevo malestar en la cultura? Variaciones sobre la crisis de la modernidad. CIS. Madrid.

ROUDINESCO, E. (1993). Jacques Lacan. Anagrama. Barcelona. 1995.

SANTAMARINA, C. y MARINAS, J.M. (1994a). "La investigación investigada. Contexto y categorías de los estudios de consumo en España" en Revista Política y Sociedad, $\mathrm{n}^{\mathrm{o}}$ 16. Madrid.

SANTAMARINA, C. (1994b). "Las palabras del mercado" en Revista de Occidente n ${ }^{\circ}$ 162. Noviembre 1994.

SENNET, R. (1998). La corrosión del carácter. Las consecuencias personales del trabajo en el nuevo capitalismo. Anagrama. Barcelona. 2000.

SHIELDS, R. (1992). Life style Schopping. The Subjet of Consumption. London. Routledge.1992.

SHILLING, C. (1993). The body and social theory. Sage. London.

SIMMEL, G. (1900). Filosofía del dinero. Instituto de Estudios Políticos. Madrid. 1977.

SIMMEL, G. (1903). "Las grandes urbes y la vida del espíritu". En SIMMEL, G. (1986). El individuo y la libertad. Ensayos de crítica de la Cultura. Península. Barcelona.

SIMMEL, G. (1895)."La moda". En SIMMEL, G. (1989). Sobre la aventura. Ensayos filosóficos. Península. Barcelona.

SIMMEL, G (1911). "El concepto y la tragedia de la cultura". En SIMMEL, G. (1989). Sobre la aventura. Ensayos filosóficos. Península. Barcelona.

SIMMEL, G. (1903). "Las grandes urbes y la vida del espíritu". En SIMMEL, G. (1986). El individuo y la libertad. Ensayos de crítica de la Cultura. Península. Barcelona.

SIMMEL, G. (1917). "El individuo y la libertad". En SIMMEL, G. (1986). El individuo y la libertad. Ensayos de crítica de la Cultura. Península. Barcelona. 
SOLDEVILlA, C. (1998). Estilo de vida. Hacia una teoría psicosocial de la acción. Entinema. Madrid.

SPENCER, H. (1877-1896). “Principios de Sociología”. Revista de Occidente. Madrid. 1947.

TURNER, B.S. (1984). El cuerpo y la sociedad. Exploraciones en teoría social. FCE. México. 1989.

VEBLEN, T. (1899). Teoría de la clase ociosa. FCE. México. 1974.

VERDU, V. (2000). "La nueva élite de los ‘bobos'". El País. 15.6.2000.

WEBER, M. (1901). "La ética protestante y el espíritu del capitalismo". En WEBER, M. (1920). Ensayos sobre Sociología de la Religión. Taurus. Madrid. 1992. 